\title{
Radiocarbon dating legacy collections: A Bayesian analysis of high-precision AMS 14C dates from the Par-Tee site, Oregon
}

DOI:

10.1016/j.jasrep.2018.08.033

\section{Document Version}

Accepted author manuscript

Link to publication record in Manchester Research Explorer

Citation for published version (APA):

Sanchez, G. M., Rick, T. C., Culleton, B. J., Kennett, D. J., Buckley, M., Erlandson, J. M., \& Losey, R. L. (2018). Radiocarbon dating legacy collections: A Bayesian analysis of high-precision AMS 14C dates from the Par-Tee site, Oregon. Journal of Archaeological Science: Reports, 21, 833-848.

https://doi.org/10.1016/j.jasrep.2018.08.033

Published in:

Journal of Archaeological Science: Reports

\section{Citing this paper}

Please note that where the full-text provided on Manchester Research Explorer is the Author Accepted Manuscript or Proof version this may differ from the final Published version. If citing, it is advised that you check and use the publisher's definitive version.

\section{General rights}

Copyright and moral rights for the publications made accessible in the Research Explorer are retained by the authors and/or other copyright owners and it is a condition of accessing publications that users recognise and abide by the legal requirements associated with these rights.

\section{Takedown policy}

If you believe that this document breaches copyright please refer to the University of Manchester's Takedown Procedures [http://man.ac.uk/04Y6Bo] or contact uml.scholarlycommunications@manchester.ac.uk providing relevant details, so we can investigate your claim.

\section{OPEN ACCESS}




\title{
RADIOCARBON DATING LEGACY COLLECTIONS: A BAYESIAN ANALYSIS OF HIGH-PRECISION AMS ${ }^{14}$ C DATES FROM THE PAR-TEE SITE, OREGON
}

\author{
Gabriel M. Sanchez ${ }^{\mathrm{a} *}$, Torben C. Rick ${ }^{\mathrm{b}}$, Brendan J. Culletonc, Douglas J. Kennettc, Michael \\ Buckley ${ }^{\mathrm{d}}$, Jon M. Erlandsone, and Robert L. Losey ${ }^{\mathrm{f}}$ \\ aDepartment of Anthropology, University of California, Berkeley, 232 Kroeber Hall, Berkeley, CA \\ 94720-3710. \\ bepartment of Anthropology, National Museum of Natural History, Smithsonian Institution, MRC 112, \\ Washington, DC 20013-7012 \\ cDepartment of Anthropology and Institutes of Energy and the Environment, Pennsylvania State \\ University. 409 Carpenter Building, University Park, PA 16802. \\ d Manchester Institute of Biotechnology, University of Manchester, 131 Princess Street \\ Manchester M1 7DN, UK \\ ${ }^{\mathrm{e}}$ Museum of Natural \& Cultural History, University of Oregon, 1680 E 15th Ave, Eugene, OR 97403- \\ 1224. \\ fDepartment of Anthropology, University of Alberta, 13-8 Tory Building, HM, Edmonton, Alberta, \\ Canada T6G 2H4. \\ *Corresponding author \\ Email addresses: gabriels@ berkeley.edu (G.M. Sanchez), rickt@si.edu (T.C. Rick), bjc23@ psu.edu (B.J. \\ Culleton), djk23@psu.edu (D.J. Kennett), m.buckley@manchester.ac.uk (M. Buckley), \\ jerland@uoregon.edu (J.M. Erlandson), rlosey@ualberta.ca (R.L. Losey)
}

\begin{abstract}
Archaeological materials in museum collections provide an excellent opportunity for researchers to investigate social, cultural, and environmental change. However, the precision of the archaeological analysis and interpretation is dependent on a firm understanding of the site chronology. The Par-Tee site (35CLT20), located on the northern Oregon Coast, produced a large archaeological collection including artifacts and faunal remains excavated in the 1960s and 1970s. Radiocarbon dates have been obtained on materials from the Par-Tee collections by several different researchers since the 1970s, but these data have not been adequately assessed for chronometric hygiene. To establish a reliable chronology for the Par-Tee site, we obtained new high-resolution accelerator mass spectrometry (AMS) radiocarbon dates and collagen peptide mass fingerprinting of cervid bones from throughout the site. We evaluate these new radiocarbon dates along with previous radiocarbon dates from the site, using chronometric hygiene assessments and Bayesian statistics to build a refined chronology for the Par-Tee site and museum collection. Previous research suggests site habitation occurred between $350 \mathrm{cal}$ BC to cal AD 1150. Our reassessment of the site chronology suggests the primary site habitation occurred from cal AD 100-800. We also identified evidence of subsequent site occupation around cal AD 1490-1635 supporting previous interpretations of site habitation after the primary shell midden forming occupation. The latter occupation may be associated with a change in site use from a semi-sedentary village to a cemetery.
\end{abstract}

\section{Keywords}

Pacific Northwest Coast, Museum-based Research, Oregon Archaeology, Collagen Peptide Mass Fingerprinting 


\section{Introduction}

Museum-based archaeological research offers access to unique archaeological materials sometimes unobtainable through modern studies - a result of the often large-scale of latenineteenth and early twentieth-century excavations. Although concerns of decreasing museum repository space are increasing (Bawaya 2007), anthropological research of museum collections is addressing a diverse range of anthropological, biological, and conservation issues (Sholts et al. 2016). Collections-based studies, however, can be complicated by the differential excavation, recovery, and curation histories of museum collections (Bawaya 2007; Pearce 1994). As Luby et al. (2013) note, these early museum assemblages endure as legacy collections rather than as "old" excavation materials. The term legacy highlights the inherent value and the importance of museum collections from the perspective of stewardship, research, and education.

Prior to initiating museum-based studies on legacy collections, conservation, rehousing, and basic inventorying of an assemblage may need to be completed-potentially deterring researchers from museum studies (Luby et al. 2013). Museum-based research also requires understanding museum-specific catalog systems, collections processing, and field sampling strategies, the availability of associated field notes and photographs, and deaccessioning practices (Huster 2013; Luby et al. 2013; Voss 2012). Despite these and other obstacles, analysis of archaeological museum collections is an important pursuit, where large collections can be analyzed on their own, or supplement new excavations at a site (Crowell 2000; Luby et al. 2013; Rick 2007).

One of the biggest issues when conducting museum-based research — and in archaeology more generally_ is establishing the chronology of an assemblage or site (Buck et al. 1991; Finstad et al. 2013; Schweikhardt et al. 2011). Frequently, in legacy collections, older radiocarbon $\left({ }^{14} \mathrm{C}\right)$ measurements were made on composite or bulk samples of charcoal, shell, or bone. Often, samples were not corrected for isotopic fractionation, isotopic ratios were estimated rather than measured, or dates have high standard deviations that make them problematic for building chronologies (Ashmore 1999; Bronk Ramsey et al. 2004; Stuiver and Polach 1977; Taylor 1991). After proper chronometric hygiene assessments of existing ${ }^{14} \mathrm{C}$ dates, it is often desirable for archaeologists to obtain new AMS dates for sites, building potentially higher resolution chronological sequences of legacy collections (Kennett et al. 2014; Luby et al. 2013). Bayesian analysis of high-precision AMS ${ }^{14} \mathrm{C}$ dates provides an important framework for enhancing the interpretation of existing collections and increasing their broader value to the scientific community (Bronk Ramsey et al. 2004; Jew et al. 2015; Kennett et al. 2011; Thulman 2017).

In this paper, we present the results of recent, high-resolution $\mathrm{AMS}{ }^{14} \mathrm{C}$ dating and Bayesian analysis for the Par-Tee site (35CLT20), which produced a large archaeological collection from the northern Oregon Coast. The Par-Tee assemblage includes 7,000 artifacts, including bone and antler tools, as well as a massive collection of faunal materials from nearly 300 excavation units that make it one of the most intensively excavated sites along the Pacific Coast of the Americas (Colten 2002; 2015; Losey and Yang 2007; Phebus and Drucker 1979; Sanchez et al. 2016; Wellman et al. 2017). We selected thick and dense cortical bone fragments, presumably from cervids for ${ }^{14} \mathrm{C}$ dating due to their excellent preservation and widespread distribution throughout the site. Previous research suggests that elk (Cervus sp.) and deer (Odocoileus sp.) dominate the Par-Tee terrestrial mammal remains (Colten 2002; 2015) and represent the primary raw material in the bone and antler tool assemblage (Losey and Yang 2007; Sanchez et al. 2016). The cervid samples were also selected for dating because they are 
non-diagnostic fragments whose destruction would not hinder future zooarchaeological analysis. We conducted collagen peptide mass fingerprinting, also known as Zooarchaeology by Mass Spectrometry (ZooMS), for each specimen to ensure that only cervids were included in the revised chronology, obviating uncertainties associated with local marine reservoir offsets. Our analysis integrates ${ }^{14} \mathrm{C}$ dating and ZooMS to refine the Par-Tee site chronology and anchor subsistence, technological, and other analyses of the collection.

\section{The Archaeology of the Northern Oregon Coast}

The northern Oregon Coast is part of the Pacific Northwest Coast Culture Area, which encompasses the region from Cape Mendocino in Northern California to Yakutat Bay, Alaska (Drucker 1955; Goddard 1945). The section of the Oregon Coast near the mouth of the Columbia River and south along the Clatsop Plains is an area culturally associated with the Chinookan speaking Clatsop and the Salish speaking Tillamook (Jacobs 2003; Silverstein 1990). Late Holocene age occupations predominate the archaeology of the Clatsop Plains. The late Holocene residential pattern of the Lower Columbia and northern Oregon Coast is commonly associated with permanent to semi-permanent villages inhabited during a majority of the year and for extended periods of time (Aikens et al. 2011). These residences were likely supported by storage-based economies (Aikens et al. 2011; Ames 2003). Complex social institutions like those observed during and after European contact are considered one of the hallmarks of the late Holocene cultural manifestations of the region (Aikens et al. 2011; Ames 2003).

In Seaside, Oregon three sites have been the focus of archaeological research: Par-Tee, Palmrose (35CLT47), and Avenue Q (34CLT13). George Phebus of the Smithsonian Institution and avocational archaeologist Robert Drucker excavated the three sites from the mid-1960s to the late 1970s (Phebus and Drucker 1973; 1979). Subsequent excavations at Palmrose and Avenue Q were conducted by the Oregon State Museum of Anthropology, University of Oregon (Connolly 1992). Based on the previous research, Palmrose was occupied from about 2335-1745 cal BC to cal AD 50-535 (Connolly 1992), Avenue Q from 1925-1225 cal BC to cal AD 690-995 (Connolly 1992), and Par-Tee from 350 cal BC to cal AD 1150 (Losey and Yang 2007; Sanchez et al. 2016).

Palmrose is recognized to contain one of the earliest known large plank houses on the southern Northwest Coast, its estimated size being 12 × 6 m (Aikens et al. 2011; Ames and Maschner 1999; Connolly 1992). The plank house appears to have been built and rebuilt several times from 800 BC to AD 400 (Ames and Maschner 1999). The Palmrose site produced a diverse artifact and faunal assemblage that includes a number of zoomorphic and anthropomorphic carved bone and antler artifacts (Aikens et al. 2011; Connolly 1992). While faunal remains from the Palmrose collection excavated by Phebus and Drucker were formerly controlled by private individuals, it is currently curated at the Museum of Natural and Cultural History, University of Oregon.

Avenue Q appears to post-date the Palmrose occupation. No residential structures are known from the site, perhaps a result of the small-scale of the excavations and historic impacts related to city development. Analysis of mollusk shells from Palmrose and Avenue Q suggest that horse clam (Tresus capax), butter clam (Saxidomus giganteus), and littleneck clam (Protothaca staminea) were constituents of the shell middens (Connolly 1995). Connolly (1995) demonstrated that the mollusks indicate the former presence of an estuary nonexistent today due to the prograding coastline associated with the formation and growth of the Clatsop Plains. 


\section{Archaeological Investigations at Par-Tee}

The Par-Tee site is located in the city of Seaside, south of the Columbia River mouth at the southern extent of the Clatsop Plains (Figure 1). Phebus and Drucker's excavations at ParTee included the excavation of at least $2565 \times 5 \mathrm{ft}$ wide test units $\left(\sim 550 \mathrm{~m}^{2}\right)$, dug in $1 \mathrm{ft}$ arbitrary levels, with recovery of materials from excavated sediments screened over $1 / 4$ in sieves (Colten 2002; 2015; Losey and Power 2005; Losey and Yang 2007; Phebus and Drucker 1973; 1979).

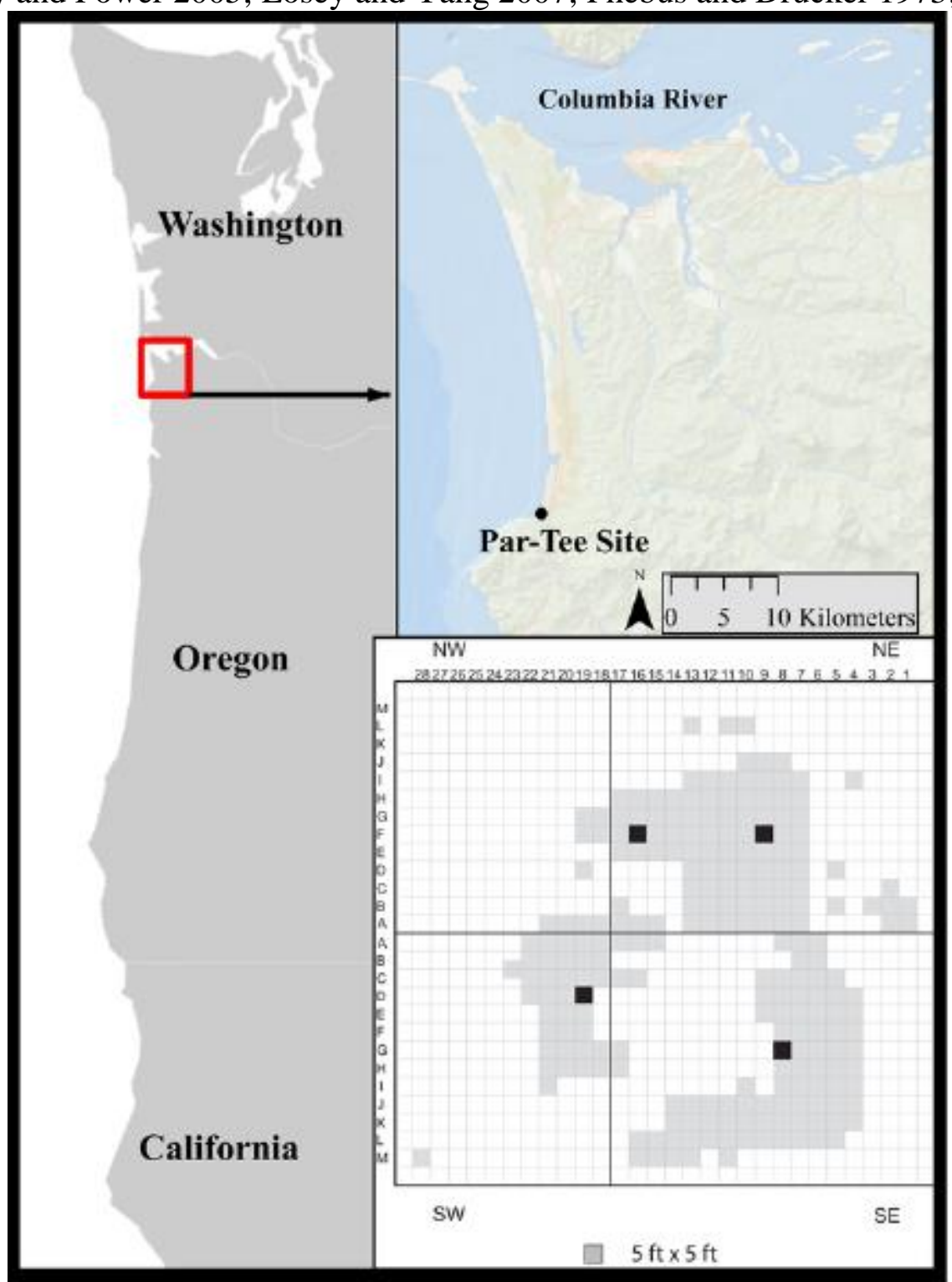

Figure 1. Overview of the northern Oregon Coast, the location of the Par-Tee site, and a grid map of the site depicting ${ }^{14} \mathrm{C}$ sampled excavation units.

Par-Tee is the largest Northwest Coast archaeological collection south of the Ozette site in Washington. Estimates suggest half of all artifacts collected during controlled excavations on the Oregon Coast originate from the Par-Tee site (Colten 2015; Losey and Power 2005; Lyman 1991). Despite the presence of the extensive collections, the Par-Tee site remains only partially reported (Lyman 1991; Phebus and Drucker 1973; 1979) with the majority of case-studies published in the last two decades and the vast majority of the collection never reported on 
(Colten 2002; 2015; Losey and Power 2005; Losey and Yang 2007; Sanchez et al. 2016; Wellman et al. 2017). The Par-Tee assemblage has been housed at the Smithsonian's National Museum of Natural History since the 1970s and has been the subject of intensive Smithsonian collections care and preservation work that includes rehousing, decompressing, cataloging, and the identification of all faunal materials to general class (i.e., bird, fish, and mammal).

Previous studies differ in their interpretations regarding the duration, seasonality, and use of the Par-Tee site by indigenous people. At present, archaeologists interpret the Par-Tee site as a village that was occupied year-round (Arbolino et al. 2005). This interpretation is supported by vertebrate faunal analyses from the site that documented a variety of fishes, mammals, and birds, likely harvested during multiple seasons of the year (Colten 2002). Based on ethnographic and ethnohistorical accounts, Minor (1983) proposed that Seaside village sites, including Par-Tee, were inhabited during the fall salmon-fishing season as part of broader seasonal shifts in the indigenous settlement-subsistence patterns of the Northern Oregon Coast. According to the model, people alternated fishing grounds from the lower Columbia River, in the summer, to the Clatsop Plains in the fall. However, recent research supports the interpretation of Par-Tee as a semi-sedentary and year-round occupation (Arbolino et al. 2005; Colten 2002).

The Par-Tee artifact assemblage includes more than 7,000 artifacts, including projectile points and other flaked stone tools, 23 whale bone atlatls and atlatl fragments, antler digging stick handles and a diverse set of bone harpoon heads, composite toggling harpoons, and unilateral and bilateral barbed points (Losey 2010; Moss 2011). The assemblage also contains an assortment of awls and bone needles that possibly indicate the production of fishing nets, basket making, weaving, and sewing (Losey 2010; Moss 2011). The interpretation that woodworking occurred is supported by the presence of bone and antler handles for attaching adze blades in addition to the presence of used basalt spall choppers, elk antler wedges, and chisels and adzes produced from elk metapodials (Losey 2010; Moss 2011). The assemblage also holds a number of zoomorphic and anthropomorphic items as well as embellished artifacts such as incised bone and antler tools (Losey 2010; Moss 2011). Lastly, several pendant-like items from the site have carefully incised geometric designs and perforations including a perforated sturgeon (Acipenser sp.) opercle (Losey 2010).

According to Arbolino et al. (2005), following the primary shell midden forming occupation of Par-Tee, people utilized the site as a burial ground. The majority of burials at ParTee post-date the primary shell midden forming occupation based on previously reported ${ }^{14} \mathrm{C}$ and stratigraphic data. The human burials were shallow, flexed inhumations that were interred in the shell midden after site abandonment (Arbolino et al. 2005). Historic era artifacts support the presence of an even more recent occupation (post 1888). These include a bone handled pocket knife, square cut nails, Euro-American and Eurasian refined earthenware and porcelain ceramics, and other historic era artifacts. Ceramics produced by the George Jones' Stoke-on-Trent were manufactured around 1864-1873 and a J\&G Meakin ceramic fragment was produced around 1888-1891 (Kowalsky and Kowalsky 1999). Therefore, the site appears to have three occupations, the primary shell midden, the later mortuary component, and a late $19^{\text {th }}$ century historic era occupation.

\subsection{Radiocarbon Dating: Previously Reported and Unreported Dates}

Previous reports present $33{ }^{14} \mathrm{C}$ dates for the Par-Tee site. Conventional radiometric ${ }^{14} \mathrm{C}$ dating suggests that the occupation of Par-Tee occurred over a period of roughly 1500 years, between approximately 350 cal BC and cal AD 1150 (2300-800 cal BP) (Arbolino et al. 2005; 
Colten 2002; Losey and Yang 2007; Sanchez et al. 2016). These dates derive from research spanning the last four decades. Significant advancements in ${ }^{14} \mathrm{C}$ dating warrant a reanalysis of the earliest dates reported.

Previous work by Smithsonian researchers reported $25{ }^{14} \mathrm{C}$ dates (Arbolino et al. 2005; Phebus and Drucker 1979). Six high-resolution AMS dates were published by Losey and Yang (2007) and two dates were obtained by Sanchez et al. (2016). The majority of ${ }^{14} \mathrm{C}$ samples submitted by Phebus and Drucker $(n=24)$ were on large, composite charcoal samples. In the preparation of at least three charcoal samples (SI-653, SI-654, and SI-655) base pretreatment (e.g. $\mathrm{NaOH}, \mathrm{KOH}$ washes) was not conducted, resulting in the potential inclusion of humates, affecting the reliability of the reported dates. In addition, of the 25 dates submitted by Phebus and Drucker, direct $\delta^{13} \mathrm{C}$ measurements were made for only two charcoal samples. In the case of one sample of human remains, $\delta^{13} \mathrm{C}$ was estimated rather than measured and the collagen yield was not reported. All but one of the uncalibrated ages falls between about $2055 \pm 145 \mathrm{BP}$ and $1000 \pm 65 \mathrm{BP}$, with a single outlier (SI-588) at $3140 \pm 100 \mathrm{BP}$ (see Appendix 1). Five excavation units (SE10L, SW20G, NE12G, NE12F, and NE14G) had multiple ${ }^{14} \mathrm{C}$ dates and chronological reversals appear in all but one of these units (NE14G).

Six dates reported by Losey and Yang (2007) derive from one excavation unit (SE10L) and were AMS ${ }^{14} \mathrm{C}$ dates obtained on single marine shell samples taken from precise locations2-inch horizontal bands of sediment. The marine shells correspond with charcoal samples dated by Phebus and Drucker and provide an additional evaluation of their dates. Six marine shell samples, two Saxidomus giganteus (butter clam) and four Protothaca staminea (Pacific littleneck clam) were submitted to Beta Analytic Inc. for AMS dating, with $\delta^{13} \mathrm{C}$ measured on an isotope ratio mass spectrometer (IRMS). The conventional ages of these samples ranged only $200{ }^{14} \mathrm{C}$ years despite being derived from deposits spanning at least 62 inches $(157.5 \mathrm{~cm})$ of apparently well-stratified midden deposits (Table 1). Several samples from different depths produced identical dates and one chronological and stratigraphic reversal.

Table 1. AMS ${ }^{14} \mathrm{C}$ dates on marine shells from 35CLT20 reported by Losey and Yang (2007), with provenience, species identification, conventional age, $\delta^{13} \mathrm{C}$, and calibrated age. Dates calibrated through the Marine13 calibration curve (Reimer et al. 2013) assuming a local marine reservoir effect $(\Delta R)$ of $240 \pm 50{ }^{14} \mathrm{C}$ years after Erlandson and Moss (1999).

\begin{tabular}{|c|c|c|c|c|c|}
\hline Lab \# & $\begin{array}{c}\text { Provenience: } \\
\text { Unit/Level } \\
\text { (depth in inches) }\end{array}$ & $\begin{array}{l}\text { Material } \\
\text { Dated }\end{array}$ & $\begin{array}{l}\text { Conventional } \\
{ }^{14} \mathrm{C} \text { age }\end{array}$ & $\begin{array}{l}\boldsymbol{\delta}^{13} \mathbf{C} \\
(\% 0 \\
\text { VPDB })\end{array}$ & $\begin{array}{c}\text { Calendar Age } \\
\text { Range } \\
(95.4 \% \text { CI })\end{array}$ \\
\hline $\begin{array}{c}\text { Beta- } \\
196687\end{array}$ & $\begin{array}{c}\text { SE10L, level 5, } \\
\text { 52-54" }\end{array}$ & $\begin{array}{c}\text { Protothaca } \\
\text { staminea }\end{array}$ & $1980 \pm 40$ & -2.2 & 90 BC-AD 125 \\
\hline $\begin{array}{c}\text { Beta- } \\
196688\end{array}$ & $\begin{array}{c}\text { SE10L, level 6, } \\
66-68^{\prime \prime}\end{array}$ & $\begin{array}{c}\text { Saxidomus } \\
\text { giganteus }\end{array}$ & $1980 \pm 40$ & -1.3 & 90 BC-AD 125 \\
\hline $\begin{array}{c}\text { Beta- } \\
196689\end{array}$ & $\begin{array}{c}\text { SE10L, level 7, } \\
\text { 70-72" }\end{array}$ & $\begin{array}{c}\text { Protothaca } \\
\text { staminea }\end{array}$ & $2080 \pm 40$ & -1.5 & 205 BC-AD 5 \\
\hline $\begin{array}{c}\text { Beta- } \\
196690\end{array}$ & $\begin{array}{c}\text { SE10L, level 8, } \\
84-86 "\end{array}$ & $\begin{array}{c}\text { Protothaca } \\
\text { staminea }\end{array}$ & $2060 \pm 40$ & -2.3 & 190 BC-AD 25 \\
\hline $\begin{array}{c}\text { Beta- } \\
196691\end{array}$ & $\begin{array}{c}\text { SE10L, level 9, } \\
98-100^{\prime \prime}\end{array}$ & $\begin{array}{c}\text { Saxidomus } \\
\text { giganteus }\end{array}$ & $2080 \pm 40$ & -0.6 & 205 BC-AD 5 \\
\hline $\begin{array}{c}\text { Beta- } \\
196692\end{array}$ & $\begin{array}{l}\text { SE10L, level 10, } \\
\text { 116-118" }\end{array}$ & $\begin{array}{c}\text { Protothaca } \\
\text { staminea }\end{array}$ & $2180 \pm 40$ & -2.0 & 375 BC-AD 110 \\
\hline
\end{tabular}


Sanchez et al. (2016) reported two AMS ${ }^{14} \mathrm{C}$ dates, one for a humpback whale phalanx and the other from an elk bone harpoon tip embedded in the whale bone. The whale bone and harpoon tip came from the southwest site area from unit $21 \mathrm{~F}$ level 4 . Calibrating the ${ }^{14} \mathrm{C}$ date from the elk bone suggests that opportunistic whaling potentially occurred on the northern Oregon Coast around cal AD 430-550 (see Losey and Yang 2007). The date from the humpback whale phalanx produced an age of $2120 \pm 15{ }^{14} \mathrm{C}$ yr BP with estimated marine reservoir offsets between $210 \pm 36{ }^{14} \mathrm{C}$ yr to $220 \pm 37{ }^{14} \mathrm{C}$ yr, providing a date of cal AD 400-610 (Sanchez et al. 2016:401-402).

The 25 radiocarbon dates obtained by Phebus and Drucker present numerous interpretative challenges. First, as previously discussed, composite samples of wood are unreliable due to the combination of separate entities, resulting in the dating of multiple events rather than more discrete cultural activities (Ashmore 1999). Second, in Pacific Northwest rainforests, long-lived trees and drift logs were commonly a source of fuel, so dates of multiple unidentified charcoal fragments are likely significantly offset by in-built age and/or the 'old wood' effect (Dee and Bronk Ramsey 2014; Kennett et al. 2002; Sanchez et al. 2016; Schiffer 1986). Lastly, samples that lack stable carbon isotope measurements are prone to inaccuracies and it is unclear precisely how these were measured, raising questions about correcting these dates. Furthermore, several of these dates have large standard deviations ( $>100$ years) that raise additional questions about their accuracy. For all these reasons, in re-examining the potential age range for Par-Tee site human occupation, we follow basic principles of chronometric hygiene (Fitzpatrick and Jew 2018; Hunt and Lipo 2006; Pettitt et al. 2003; Spriggs 1989; Wilmshurst et al. 2011), in excluding all dates previously reported by Phebus and Drucker $(1973 ; 1979)$. In addition, we exclude previously reported ${ }^{14} \mathrm{C}$ dates from marine organisms (Losey and Yang 2007; Sanchez et al. 2016) to avoid uncertainties associated with corrections for regional marine reservoir effects.

\section{Material and Methods}

The Smithsonian Institution's National Museum of Natural History houses all the ParTee collections and materials sampled in this study. To maintain standard sampling strategies, we rely on a new series of high-resolution ${ }^{14} \mathrm{C}$ dates for the current study and exclude previously reported AMS ${ }^{14} \mathrm{C}$ dates from marine organisms (Losey and Yang 2007; Sanchez et al. 2016). However, we include one previously reported ${ }^{14} \mathrm{C}$ date on elk bone reported by Sanchez et al. (2016). Fifteen bone samples from four excavation units (NE9F, NE16F, SW19D, and SE8G) from the Par-Tee assemblage were sampled for the analysis. Rick and Sanchez selected three bone samples per unit, except for SW19D where five samples were selected and NE9F with four samples. Individual samples derive from distinct arbitrary excavation levels. To minimize our impact on the collection, we selected non-diagnostic long bone fragments for the study that appeared to be Cervidae remains based on cortical bone thickness or metapodial groove presence. To our knowledge, none of the samples has ever been treated with any pesticides or other materials that may influence our results. Rick used sterile surgical blades to remove $0.5-1 \mathrm{~g}$ of bone material, removing two samples from each specimen. Subsamples were sent to the Human Paleoecology and Isotope Geochemistry Laboratory at Pennsylvania State University (PSU) for pretreatment and later the W.M. Keck Carbon Cycle AMS Laboratory, University of California-Irvine for AMS dating. In addition, the PSU AMS Facility analyzed two samples for AMS dating. The second sub-sample was sent to the Manchester Institute of Biotechnology, University of Manchester for ZooMS analysis. 


\subsection{ZooMS Methods}

Advances in faunal identification methods through molecular fingerprinting provide researchers the opportunity to limit research impacts on museum archaeological collections (Buckley et al. 2008; 2014; Collins et al. 2010; Richter et al. 2011) while maximizing data gathering potential. Collagen peptide mass fingerprinting (i.e., ZooMS) facilitates the use of highly fragmented faunal remains in research, allowing for the molecular barcoding of archaeological samples - even those in which ancient DNA (aDNA) is no longer readily retrieved-to family, genus, and in some cases, species level identification (Rybczynski et al. 2013; Speller et al. 2016). Collagen is the most abundant protein in bone and preserves for millions of years in some environments (Rybczynski et al. 2013). Thus, collagen peptide mass fingerprinting allows researchers to identify highly fragmented faunal remains to better understand animals present in an assemblage, human processing, and non-cultural taphonomic factors affecting the representation of species (Buckley et al. 2017).

ZooMS collagen fingerprinting was carried out following van der Sluis et al. (2014). Bone powder was demineralized with $0.6 \mathrm{M} \mathrm{HCl}$ overnight and ultrafiltered into ammonium bicarbonate $(50 \mathrm{mM})$ using $10 \mathrm{kDa}$ molecular weight cut-off filters (Vivaspin, UK). The retentate was then digested with $0.4 \mu \mathrm{g}$ sequencing grade trypsin (Promega, UK) overnight at $37^{\circ} \mathrm{C}$. Subsequently the digests were acidified to $0.1 \%$ trifluoroacetic acid (TFA) and the peptides purified and fractionated into $10 \%$ and $50 \%$ acetonitrile in $0.1 \%$ TFA fractions using C18 ZipTips (OMIX, UK) following Buckley et al. (2009). After centrifugal evaporation and resuspension in $10 \mu \mathrm{L} 0.1 \%$ TFA, $1 \mu \mathrm{L}$ samples were spotted with an equal amount of $\alpha$-cyano hydroxycinnamic acid matrix onto a Bruker stainless steel Matrix Assisted Laser Desorption Ionization (MALDI) target plate and allowed to air dry. The fingerprints were then acquired using a Bruker Ultraflex II MALDI mass spectrometer with up to 2,000 laser acquisitions over the mass/charge $(\mathrm{m} / \mathrm{z})$ range of 700-3700. Spectra were compared with those of previous publications (e.g., Buckley \& Kansa 2011; Buckley et al. 2010; 2017) for identification by matching selected peptide markers.

\subsection{AMS Methods}

At PSU, bone collagen was extracted and purified using the modified Longin method with ultrafiltration (Brown et al. 1988; Hoggarth et al. 2014). Samples (200-400 mg) were demineralized for $24-36 \mathrm{hr}$ in $0.5 \mathrm{~N} \mathrm{HCl}$ at $5^{\circ} \mathrm{C}$, followed by a brief $(<1 \mathrm{hr}$ ) alkali bath in $0.1 \mathrm{~N}$ $\mathrm{NaOH}$ at room temperature to remove humates. The pseudomorph was rinsed to neutrality in multiple changes of $18.2 \mathrm{M} \Omega \mathrm{H}_{2} \mathrm{O}$, and then gelatinized for $10 \mathrm{hr}$ at $60^{\circ} \mathrm{C}$ in $0.01 \mathrm{~N} \mathrm{HCl}$. Gelatin solution was pipetted into precleaned Centriprep ${ }^{\circledR} 30$ ultrafilters (retaining $>30 \mathrm{kDa}$ molecular weight gelatin) and centrifuged three times for $20 \mathrm{~min}$, diluted with $18.2 \mathrm{M} \Omega \mathrm{H}_{2} \mathrm{O}$ and centrifuged three more times for $20 \mathrm{~min}$ to desalt the solution. More detailed ultrafilter cleaning methods are described in (McClure et al. 2010). Ultrafiltered collagen was lyophilized and weighed to determine percent yield as a first evaluation of the degree of bone collagen preservation. Carbon and nitrogen concentrations and stable isotope ratios were measured at the PSU Light Isotope Laboratory with a Costech EA (ECS 4010), Thermo Finnigan Conflo IV gas handling device, and a Thermo Finnigan Delta V analyzer. Sample quality was evaluated by $\%$ crude gelatin yield, $\% \mathrm{C}, \% \mathrm{~N}$, and $\mathrm{C}: \mathrm{N}$ ratios before AMS ${ }^{14} \mathrm{C}$ dating. $\mathrm{C}: \mathrm{N}$ ratios for the samples were around 3.43 to 3.26, indicating good collagen preservation (DeNiro 1985; van Klinken 1999). ${ }^{14} \mathrm{C}$ samples ( 2.5mg) were combusted for $3 \mathrm{hr}$ at $900^{\circ} \mathrm{C}$ in vacuum-sealed quartz tubes 
with $\mathrm{CuO}$ wire and $\mathrm{Ag}$ wire. Sample $\mathrm{CO}_{2}$ was sent to W.M. Keck Carbon Cycle AMS facility at the University of California-Irvine (UCIAMS) or the PSU AMS Facility (PSUAMS), where it was reduced to graphite at $550^{\circ} \mathrm{C}$ using $\mathrm{H}_{2}$ and a Fe catalyst, with reaction water drawn off with $\mathrm{Mg}\left(\mathrm{ClO}_{4}\right)_{2}$ (Santos et al. 2004) (Table 6). Graphite samples were pressed into targets in $\mathrm{Al}$ cathodes and loaded on the target wheel for AMS analysis. ${ }^{14} \mathrm{C}$ ages were corrected for massdependent fractionation with measured $\delta^{13} \mathrm{C}$ values on the AMS (Stuiver and Polach 1977) and compared with samples of Pleistocene whale bone (background, >50 ka BP), late Holocene bison bone $\left(\sim 1850{ }^{14} \mathrm{C} \mathrm{BP}\right)$, late AD 1800 s cow bone, and OXII oxalic acid standards.

\subsection{Bayesian Statistical Modeling}

Bayesian approaches to constructing archaeological chronologies incorporate prior information regarding the archaeological site(s) and regional culture histories in the formulation of models (Bayliss and Ramsey 2004; Bayliss et al. 2007; Kennett et al. 2011). Thus, new data are analyzed in a framework within the context of prior knowledge (Bayliss et al. 2007). For our analysis, ${ }^{14} \mathrm{C}$ dates were calibrated using the IntCal13 calibration curve (Reimer et al. 2013) and models developed in OxCal 4.3 (Bronk Ramsey 1995). Bayesian analysis in OxCal allows researchers to situate dated events into models defining a sequence, a phase(s), and statistically calculate terminus ante quem and terminus post quem dates and their span when considering the chronology of a site or of specific events (Bayliss et al. 2007; Bronk Ramsey 1995; Hamilton and Krus 2018). Two statistics calculated in OxCal aid in the assessment of the reliability of a model: indices of agreement and convergence. For each dated sample in the models generated by OxCal, an agreement index is calculated. An overall agreement index for the model itself is also determined calculated from the individual agreement indices (Bayliss et al. 2007). As Bronk Ramsey (1995) notes, model agreement indices should not fall below 60\%. If the index of agreement falls below $60 \%$ (analogous to 0.05 significance level in a $\mathrm{X}^{2}$ test), the ${ }^{14} \mathrm{C}$ results or the model is problematic (Bayliss et al. 2007). Therefore, agreement indices allow researchers to test for unreliable models or dates (Bayliss et al. 2007; Bronk Ramsey 1995).

Kennett et al. (2011) suggest five considerations in model building. These include precise stratigraphic excavation and selection of ${ }^{14} \mathrm{C}$ samples, selection of short-lived organisms for dating, proper protocols of sample processing, understanding the taphonomic processes affecting sites and samples, and application of the appropriate model type and settings. A limitation of working with museum collections, especially those resulting from coarse-grained excavation methods compared to modern excavation practices, is that precise stratigraphic relationships may not be known or recorded and taphonomic processes affecting the site unspecified. However, OxCal provides a means to construct models to test a priori knowledge of the site and refine preexisting concepts.

Bayesian analysis provides an opportunity to create a revised chronology for the Par-Tee site and more reliable estimates for the duration of occupation. In creating models for the site, we assumed that all deposits were in undisturbed stratigraphic order. To test this assumption and the stratigraphic integrity of the site and ${ }^{14} \mathrm{C}$ samples we first created simple calibration models for individual excavation units during the first iteration of dating. ${ }^{14} \mathrm{C}$ dates were placed in a sequence in OxCal with boundary start and end dates calculated.

\section{Results}

5.1 ZooMS Analysis 
ZooMS analysis confirmed that all but one of the 15 bone samples selected were from cervids due to the presence of peptide markers at $\sim \mathrm{m} / \mathrm{z} 1196.6, \mathrm{~m} / \mathrm{z} 1427.7, \mathrm{~m} / \mathrm{z} 1550.8, \mathrm{~m} / \mathrm{z}$ 2131.1, $\mathrm{m} / \mathrm{z} 2883.4$ and $\mathrm{m} / \mathrm{z} 3033$ (Figure 2). The one specimen found to derive from a noncervid yielded markers not matching known collagen fingerprint for reference taxa. The noncervid sample is derived NE9F-3 and measured $\delta^{13} \mathrm{C}$ and $\delta^{15} \mathrm{~N}$ values indicate isotope values consistent with marine organisms, in this case a marine mammal (see below). ZooMS analysis confirmed that our fragmentary bone samples were terrestrial in origin, supporting the use of the IntCal curve, with one exception.

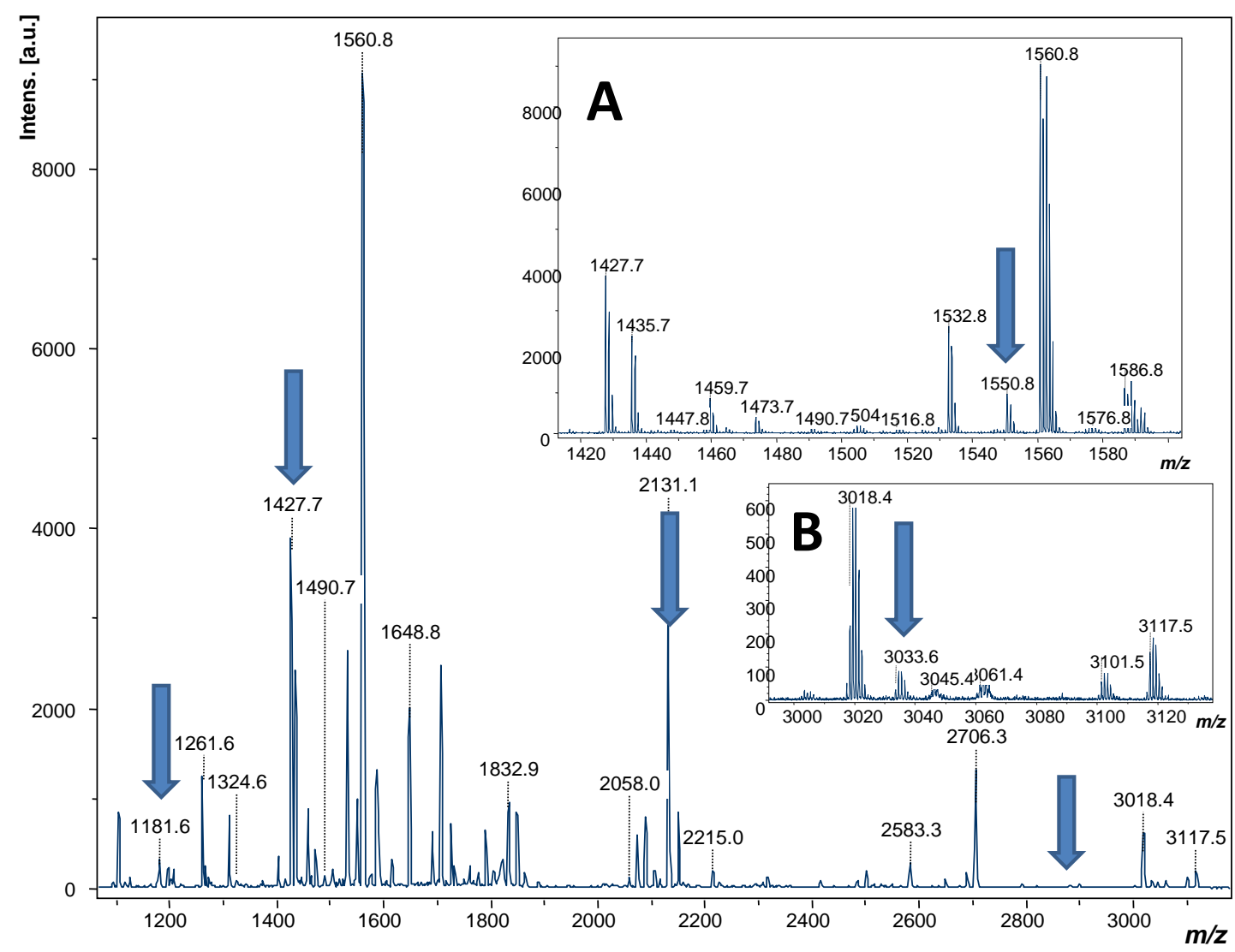

Figure 2. MALDI-ToF mass spectrum of a collagen tryptic digest from sample NE16f-6, with markers collectively matching those for cervine deer at $m / z$ 1196.6, 1427.7, 1550.8 (inset A), 2131.1, 2883.4 and 3033.4 (inset B).

\subsection{Chronology Building First Iteration: Calibration}

\section{$N E 16 F$}

The materials from excavation unit NE16F include three samples from levels 8,6 , and 5 (Figure 3). The conventional age for the specimens range from $1735 \pm 20 \mathrm{BP}$ to $1535 \pm 15 \mathrm{BP}$, with isotopic values typical of a terrestrial herbivore (Table 2). The agreement indices for the model are $A_{\text {model }}=73.3$ and $A_{\text {overall }}=73.7$ within the tolerance suggested by Bronk Ramsey (1995). No significant stratigraphic reversals are noted in the unit. 
Figure 3. 35CLT20 Unit NE16F South Wall profile. Level provenience of ${ }^{14} \mathrm{C}$ samples noted. Adapted from Par-Tee excavation notes.

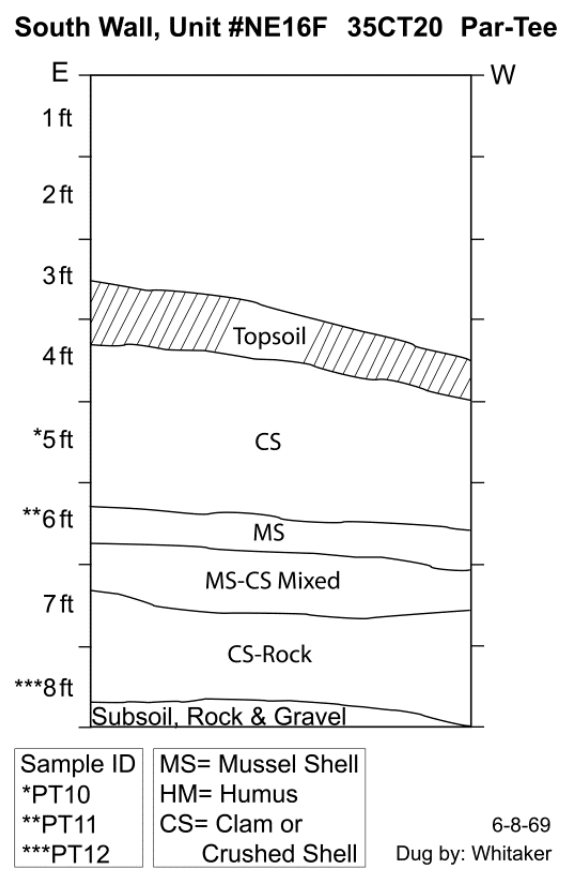

Table 2. AMS ${ }^{14} \mathrm{C}$ dates on cervid bones from first round of modeling for NE16F. Context designations derived from Phebus and Drucker excavation field notes.

\begin{tabular}{|c|c|c|c|c|c|c|c|}
\hline $\begin{array}{l}\text { Sample } \\
\text { ID }\end{array}$ & $\begin{array}{l}\text { PSU/UCIAMS } \\
\#\end{array}$ & $\begin{array}{l}\boldsymbol{\delta}^{13} \mathbf{C} \\
(\% 0, \\
\text { VPDB })\end{array}$ & $\begin{array}{l}\boldsymbol{\delta}^{15} \mathbf{N} \\
(\%) \\
\text { Atm } \\
\left.N_{2}\right)\end{array}$ & Context & $\begin{array}{l}\text { Conventional } \\
{ }^{14} \mathrm{C} \text { Age } \mathrm{BP}\end{array}$ & $\begin{array}{l}\text { cal AD } \\
(95.4 \% \\
\text { CI })\end{array}$ & $\begin{array}{l}\text { Modeled } \\
\text { cal AD } \\
(95.4 \% \\
\text { CI })\end{array}$ \\
\hline
\end{tabular}

\begin{tabular}{|c|c|c|c|c|c|c|c|}
\hline PT12 & $7052 / 174931$ & -23.7 & 5.1 & $\begin{array}{l}\text { Level 8- } \\
\text { Crushed } \\
\text { shell and } \\
\text { rock } \\
\text { matrix }\end{array}$ & $1735 \pm 20$ & $\begin{array}{l}240- \\
380\end{array}$ & $250-385$ \\
\hline PT11 & $7051 / 174930$ & -25.9 & 4.3 & $\begin{array}{l}\text { Level 6- } \\
\text { Mixed } \\
\text { mussel } \\
\text { shell and } \\
\text { clam } \\
\text { shell } \\
\text { matrix }\end{array}$ & $1535 \pm 15$ & $\begin{array}{l}430- \\
575\end{array}$ & $425-490$ \\
\hline PT10 & $7050 / 174929$ & -25.5 & 4.0 & $\begin{array}{l}\text { Level 5- } \\
\text { Clam } \\
\text { shell } \\
\text { matrix }\end{array}$ & $1570 \pm 15$ & $\begin{array}{l}425- \\
540\end{array}$ & $440-540$ \\
\hline
\end{tabular}


Four samples from excavation unit NE9F were dated, from levels $8(n=1), 5(n=1)$, and 3 $(n=2)$ (Figure 4). For this unit, we exclude one date from level 3 that was derived from marine mammal bone due to issues with the marine reservoir effect and unknown taxonomic designation potentially biasing calibration.

The conventional ages for the unit span from $1660 \pm 15 \mathrm{BP}$ to $330 \pm 15 \mathrm{BP}$, with isotopic values typical of a terrestrial herbivore (Table 3). The excluded marine mammal sample conventional age is NE9F-3 $2015 \pm 25$ BP (PSUAMS-1345: $\delta^{13} \mathrm{C}:-12.3$ VPDB; $\delta^{15} \mathrm{~N}: 14.7 \%$ o Atm N2). The agreement indices for the model are $A_{\text {model }}=97.9$ with an $A_{\text {overall }}=97.9$ well within the tolerance suggested by Bronk Ramsey (1995).

Figure 4. 35CLT20 Unit NE9F South Wall profile. Level provenience of radiocarbon samples noted. Adapted from Par-Tee excavation notes.

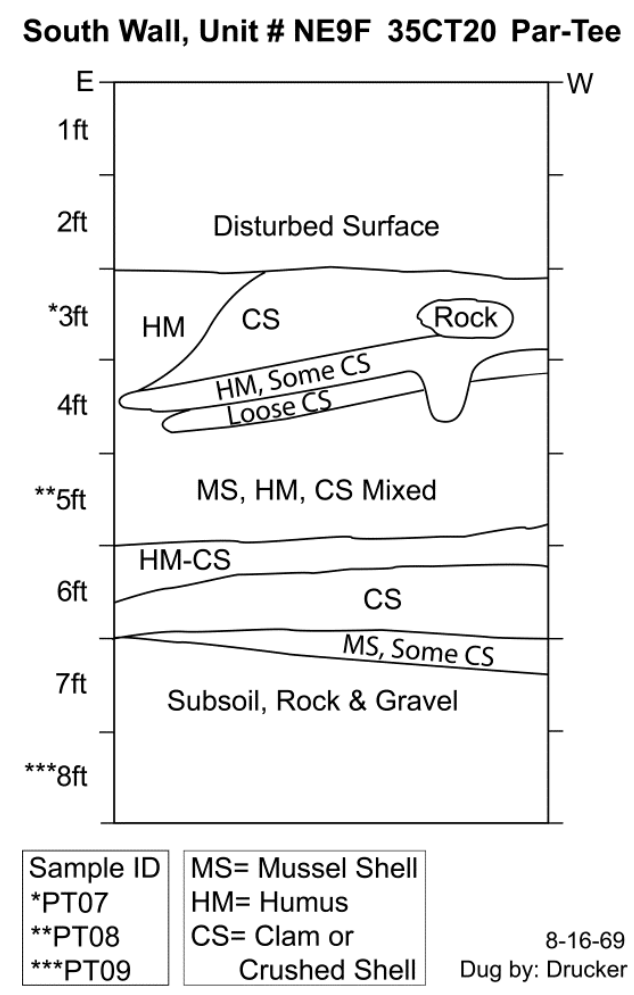

Table 3. AMS ${ }^{14} \mathrm{C}$ dates for cervid bone samples from first round of modeling for NE9F. Context designations derived from Phebus and Drucker excavation field notes.

\begin{tabular}{|c|c|c|c|c|c|c|c|}
\hline $\begin{array}{l}\text { Sample } \\
\text { ID }\end{array}$ & $\begin{array}{l}\text { PSU/UCIA } \\
\text { MS \# }\end{array}$ & $\begin{array}{l}\boldsymbol{\delta}^{13} \mathbf{C} \\
(\%, \text { VPDB })\end{array}$ & $\begin{array}{l}\mathbf{\delta}^{\mathbf{1 5}} \mathbf{N} \\
(\% 0, \text { Atm } \\
\left.\mathrm{N}_{2}\right)\end{array}$ & Context & $\begin{array}{l}\text { Conventional } \\
{ }^{14} \mathrm{C} \text { Age BP }\end{array}$ & $\begin{array}{l}\text { cal } \\
\text { AD } \\
(95.4 \\
\% \text { CI })\end{array}$ & $\begin{array}{l}\text { Modeled } \\
\text { cal AD } \\
(95.4 \% \\
\text { CI })\end{array}$ \\
\hline PT09 & $7049 / 174928$ & -25.3 & 4.1 & Level 8- & $1660 \pm 15$ & $340-$ & $340-420$ \\
\hline
\end{tabular}




\begin{tabular}{|c|c|c|c|c|c|c|c|}
\hline & & & & $\begin{array}{l}\text { Subsoil } \\
\text { rock and } \\
\text { gravel }\end{array}$ & & 420 & \\
\hline PT08 & 7048/174927 & -25.6 & 2.7 & $\begin{array}{l}\text { Level 5- } \\
\text { Mussel } \\
\text { shell, } \\
\text { clam, } \\
\text { and } \\
\text { humus } \\
\text { mixed }\end{array}$ & $1515 \pm 15$ & $\begin{array}{l}435- \\
605\end{array}$ & $470-605$ \\
\hline РT07 & $7047 / 174926$ & -22.4 & 7.0 & $\begin{array}{l}\text { Level 3- } \\
\text { Humus/c } \\
\text { lam shell } \\
\text { and } \\
\text { disturbe } \\
\text { d surface }\end{array}$ & $330 \pm 15$ & $\begin{array}{l}1490- \\
1640\end{array}$ & $\begin{array}{l}1485- \\
1640\end{array}$ \\
\hline
\end{tabular}

SE8G

The materials from excavation unit SE8G include three samples from excavation levels 7 , 5 , and 3 (Figure 5). The conventional ages for the samples range from $1770 \pm 15$ BP to $1440 \pm$ $15 \mathrm{BP}$, with isotopic values typical of a terrestrial herbivore (Table 4). The agreement indices for the model are $A=0$ outside the tolerance suggested by Bronk Ramsey (1995) due to the stratigraphic reversal present in level 5.

Figure 5. 35CLT20 Unit SE8G West Wall profile. Level provenience of radiocarbon samples noted. Adapted from Par-Tee excavation notes.

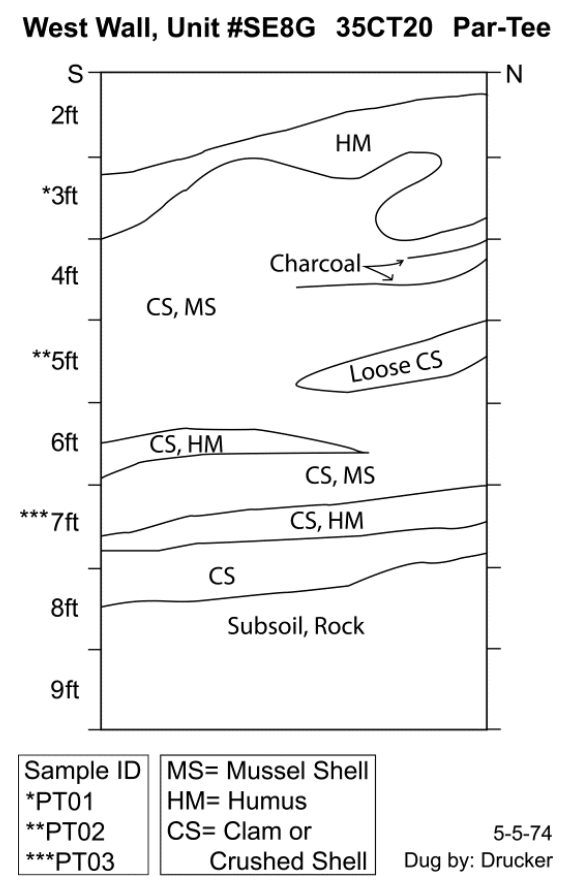


Table 4. AMS ${ }^{14} \mathrm{C}$ dates for cervid bones from first round of modeling for Unit SE8G. Context designations derived from Phebus and Drucker excavation field notes.

\begin{tabular}{|c|c|c|c|c|c|c|c|}
\hline $\begin{array}{l}\text { Sample } \\
\text { ID }\end{array}$ & $\begin{array}{l}\text { PSU/UCIAMS } \\
\#\end{array}$ & $\begin{array}{l}\boldsymbol{\delta}^{13} \mathbf{C} \\
\text { (\%o, } \\
\text { VPDB) }\end{array}$ & $\begin{array}{l}\mathbf{\delta}^{15} \mathbf{N} \\
(\% 0, \\
\text { Atm } \\
\left.N_{2}\right)\end{array}$ & Context & $\begin{array}{l}\text { Conventional } \\
{ }^{14} \mathrm{C} \text { Age BP }\end{array}$ & $\begin{array}{l}\text { cal AD } \\
(\mathbf{9 5 . 4 \%} \\
\text { CI) }\end{array}$ & $\begin{array}{l}\text { Modeled } \\
\text { cal AD } \\
(95.4 \% \\
\text { CI })\end{array}$ \\
\hline $\begin{array}{l}\text { PT03 } \\
\end{array}$ & $7043 / 174922$ & -25.1 & 4.0 & $\begin{array}{l}\text { Level 7- } \\
\text { Mixed } \\
\text { clam } \\
\text { shell, } \\
\text { mussel } \\
\text { shell, and } \\
\text { humus } \\
\text { matrix }\end{array}$ & $1590 \pm 15$ & $\begin{array}{l}415- \\
540\end{array}$ & $\begin{array}{l}\text { Not } \\
\text { included }\end{array}$ \\
\hline PT02 & $7042 / 174921$ & -21.5 & 5.4 & $\begin{array}{l}\text { Level 5- } \\
\text { Clam and } \\
\text { mussel } \\
\text { shell } \\
\text { matrix }\end{array}$ & $1770 \pm 15$ & $\begin{array}{l}225- \\
335\end{array}$ & $\begin{array}{l}\text { Not } \\
\text { included }\end{array}$ \\
\hline PT01 & $7041 / 174920$ & -23.6 & 3.8 & $\begin{array}{l}\text { Level 3- } \\
\text { Clam } \\
\text { shell and } \\
\text { overlying } \\
\text { humus }\end{array}$ & $1440 \pm 15$ & $\begin{array}{l}590- \\
650\end{array}$ & $\begin{array}{l}\text { Not } \\
\text { included }\end{array}$ \\
\hline
\end{tabular}

SW19D

The materials from excavation unit SW19D include five samples from levels 7, 6, 5, 4 and 2 (Figure 6). The conventional ages for the samples range from $1640 \pm 15 \mathrm{BP}$ to $1300 \pm 15$ $\mathrm{BP}$, with all isotopic values typical of a terrestrial herbivore (Table 5). The agreement indices for the model are $\mathrm{A}_{\text {model }}=43.8$ with an $\mathrm{A}_{\text {overall }}=48.4$ outside the tolerance suggested by Bronk Ramsey (1995) due to the stratigraphic reversal present in level 6.

Figure 6. 35CLT20 Unit SW19D South Wall profile. Level provenience of radiocarbon samples noted. Adapted from Par-Tee excavation notes. 


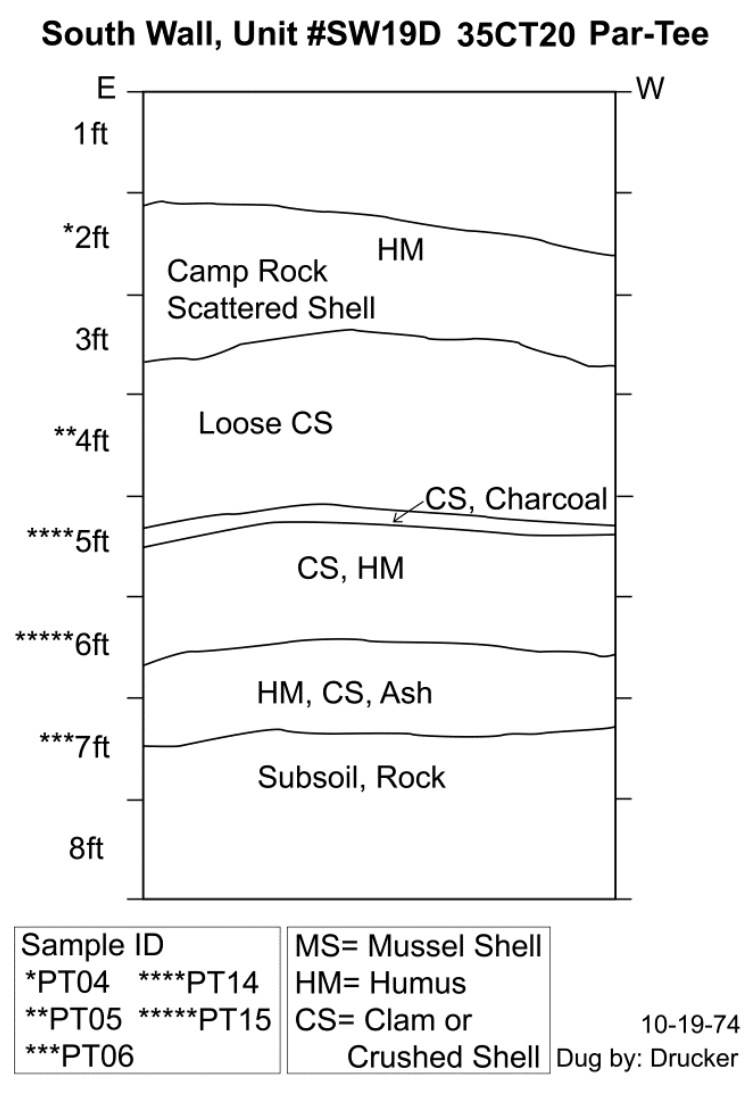

Table 5. AMS 14C dates for cervid bones from first round of modeling for SW19D. Context designations derived from Phebus and Drucker excavation field notes.

\begin{tabular}{|c|c|c|c|c|c|c|c|}
\hline $\begin{array}{l}\text { Sample } \\
\text { ID }\end{array}$ & $\begin{array}{l}\text { PSU/UCIAMS } \\
\#\end{array}$ & $\begin{array}{l}\boldsymbol{\delta}^{13} \mathbf{C} \\
\text { (\%o, } \\
\text { VPDB) }\end{array}$ & $\begin{array}{l}\boldsymbol{\delta}^{15} \mathbf{N} \\
(\% 0, \\
\text { Atm } \\
\left.N_{2}\right)\end{array}$ & Context & $\begin{array}{l}\text { Conventional } \\
{ }^{14} \mathrm{C} \text { Age BP }\end{array}$ & $\begin{array}{l}\text { cal AD } \\
(95.4 \% \\
\text { CI) }\end{array}$ & $\begin{array}{l}\text { Modeled } \\
\text { cal AD } \\
(95.4 \% \\
\text { CI })\end{array}$ \\
\hline PT06 & $7046 / 174925$ & -25.7 & 4.9 & $\begin{array}{l}\text { Level 7- } \\
\text { Sub-soil and } \\
\text { rock/mixed } \\
\text { humus, } \\
\text { clam shell, } \\
\text { and ash } \\
\text { matrix }\end{array}$ & $1640 \pm 15$ & $\begin{array}{l}350- \\
430\end{array}$ & $\begin{array}{l}\text { Not } \\
\text { included }\end{array}$ \\
\hline PT15 & $\begin{array}{l}\text { PSUAMS- } \\
1752\end{array}$ & -21.9 & 2.9 & $\begin{array}{l}\text { Level 6- } \\
\text { Mixed clam } \\
\text { shell, } \\
\text { humus ash } \\
\text { matrix }\end{array}$ & $1515 \pm 20$ & $\begin{array}{l}430- \\
605\end{array}$ & $\begin{array}{l}\text { Not } \\
\text { included }\end{array}$ \\
\hline PT14 & $\begin{array}{l}\text { PSUAMS- } \\
1751\end{array}$ & -25.7 & 3.8 & $\begin{array}{l}\text { Level 5- } \\
\text { Clam shell }\end{array}$ & $1570 \pm 20$ & $\begin{array}{l}425- \\
545\end{array}$ & $\begin{array}{l}\text { Not } \\
\text { included }\end{array}$ \\
\hline
\end{tabular}




\begin{tabular}{|c|c|c|c|c|c|c|c|}
\hline & & & & $\begin{array}{l}\text { and humus } \\
\text { matrix/clam } \\
\text { shell and } \\
\text { charcoal } \\
\text { lens }\end{array}$ & & & \\
\hline PT05 & $7045 / 174924$ & -26.2 & 4.2 & $\begin{array}{l}\text { Level 4- } \\
\text { Clam shell } \\
\text { matrix }\end{array}$ & $1300 \pm 15$ & $\begin{array}{l}665- \\
770\end{array}$ & $\begin{array}{l}\text { Not } \\
\text { included }\end{array}$ \\
\hline PT04 & $7044 / 174923$ & -25.6 & 3.6 & $\begin{array}{l}\text { Level 2- } \\
\text { Shell/humus } \\
\text { matrix }\end{array}$ & $1315 \pm 20$ & $\begin{array}{l}655- \\
770\end{array}$ & $\begin{array}{l}\text { Not } \\
\text { included }\end{array}$ \\
\hline
\end{tabular}

\subsection{Second Iteration: Models, Phases and Duration of Occupation}

As the calibrations of dates from the four units demonstrate, stratigraphic reversals are found in the southern portions of the site in units SW19D and SE8G while the northern portion of the site seems to be stratigraphically intact. These findings may be supported by site observations recorded by Phebus and Drucker in 1970 . On July $9^{\text {th }}$, field notes indicate that the:

"Upper strata of the SE quadrant of this site feature appreciable quantities of firecracked stone amidst the usual shell deposit. This [southern] area also features numerous indications of habitation such as hearths, lens[es], and structures. The absence of such traits in the midden of the NW quadrant seems to imply that that area was more properly site dump debris. This observation is consistent since the south side of the site would be the lee side and considerably more protected from the wind and weather. This condition may also exist on the Palmrose [35CLT47] site where dominant features occur primarily on the south side."

If the primary site habitation zone was in the southern portion of the site with refuse being discarded to the north, this may explain why deposits to the north appear more homogenous than sediments to the south. Otherwise, the ${ }^{14} \mathrm{C}$ reversals could be explained as a result of deposit mixing during site occupation, bioturbation, cross-cutting of discrete stratigraphic components - due to the excavation method of one foot arbitrary levels — or other natural or cultural factors (Ames 1996; Erlandson and Rockwell 1987; Jew et al. 2015; Losey 2005).

Following the first iteration of the Par-Tee calibration, we constructed a model of the site chronology based on evidence of site occupation from the ${ }^{14} \mathrm{C}$ dates without emphasizing site stratigraphy, a result of the stratigraphic reversals (Table 6 and Figure 7). Given the coarse excavation methods at the site, the presence of stratigraphic reversals, and the limited excavation notes, we determined that defining the duration of occupation and identifying discrete phases of site occupation was best explored through an analysis and calibration of AMS ${ }^{14} \mathrm{C}$ dates without reference to site stratigraphy.

We began by compiling all dates derived from the current analysis, the cervid remains, and a previously reported elk bone harpoon date (UCIAMS-137938) in chronological order in OxCal 4.3. The results appear to demonstrate a consistent occupation and cervid exploitation from cal AD 225 to cal AD 770. However, seven of the fourteen dates cluster around cal AD 415 
to cal AD 605, suggesting the possibility for intensive site use around this time with more discrete and intermittent periods of occupation.

Table 6. Heuristic Analysis of AMS ${ }^{14} \mathrm{C}$ dates from the Par-Tee site.

\begin{tabular}{cc}
\hline Lab Number & Unmodelled cal AD $(95.4 \%$ CI $)$ \\
\hline UCIAMS-174924 & $665-770$ \\
UCIAMS-174923 & $655-770$ \\
UCIAMS-174920 & $590-650$ \\
UCIAMS-174927 & $435-605$ \\
PSUAMS-1752 & $430-605$ \\
UCIAMS-174930 & $430-575$ \\
UCIAMS-137938 & $425-555$ \\
PSUAMS-1751 & $425-545$ \\
UCIAMS-174929 & $425-540$ \\
UCIAMS-174922 & $415-540$ \\
UCIAMS-174925 & $350-430$ \\
UCIAMS-174928 & $340-420$ \\
UCIAMS-174931 & $240-380$ \\
UCIAMS-174921 & $225-335$ \\
\hline
\end{tabular}

Figure 7. Calibrated AMS ${ }^{14} \mathrm{C}$ dates for the Par-Tee site ordered chronologically.

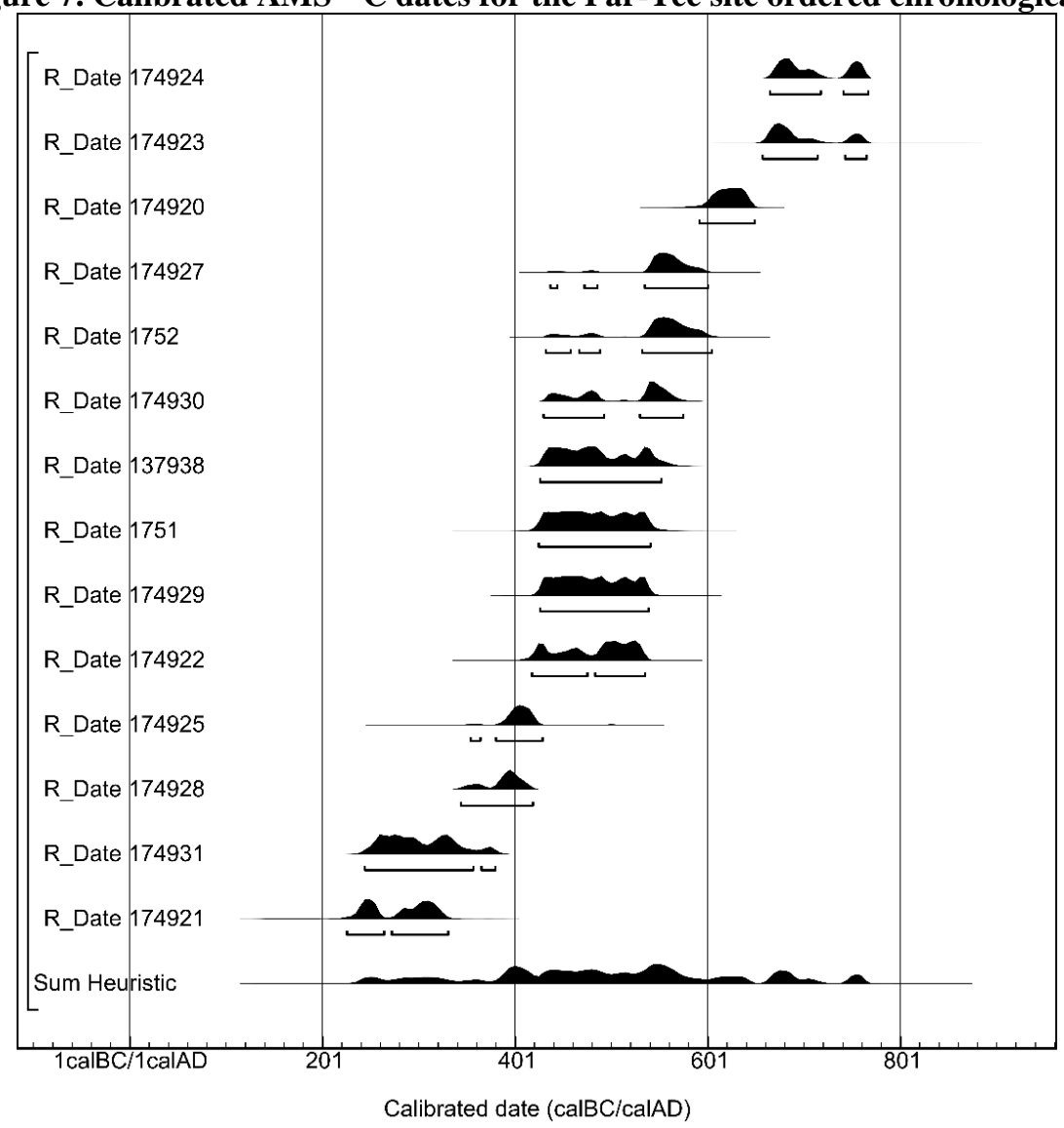




\section{Model 1: Phases}

Based on the data from the heuristic model we explored the possibility that there were discrete phases of cultural activity at the Par-Tee site, related to cervid exploitation and site use (Figure 7). The model estimates the depositional start and end dates for each phase. For the sequence we included start and end boundaries for the radiocarbon dates. Additionally, we included boundaries and phases around clusters of dates defined in the heuristic calibration, assuming these clusters of dates were a result of discrete or episodic site habitation or cervid exploitation (Table 7 and Figure 8).

The agreement indices for Model 1 are $\mathrm{A}_{\text {model }}=112.5$ and $\mathrm{A}_{\text {overall }}=109.6$.

Table 7. Model 1 Results

\begin{tabular}{|c|c|c|}
\hline Model Description & $\begin{array}{l}\text { Unmodelled cal AD (95.4\% } \\
\text { CI) }\end{array}$ & $\begin{array}{l}\text { Modelled cal AD (95.4\% } \\
\text { CI) }\end{array}$ \\
\hline Difference Span & & 350 to 630 cal yr \\
\hline Boundary End & & $665-820$ \\
\hline UCIAMS-174924 & $665-770$ & $665-765$ \\
\hline UCIAMS-174923 & 655-770 & $655-765$ \\
\hline \multicolumn{3}{|l|}{ Phase e } \\
\hline Boundary & & $600-750$ \\
\hline UCIAMS-174920 & $590-650$ & $590-650$ \\
\hline \multicolumn{3}{|l|}{ Phase d } \\
\hline Boundary & & $475-640$ \\
\hline UCIAMS-174927 & $435-605$ & 435-595 \\
\hline PSUAMS-1752 & $435-605$ & 430-595 \\
\hline UCIAMS-174930 & $430-575$ & $430-575$ \\
\hline UCIAMS-137938 & $425-555$ & 430-555 \\
\hline PSUAMS-1751 & $425-545$ & $425-545$ \\
\hline UCIAMS-174929 & $425-540$ & $430-545$ \\
\hline UCIAMS-174922 & 415-540 & $420-540$ \\
\hline \multicolumn{3}{|l|}{ Phase c } \\
\hline Boundary & & $395-520$ \\
\hline UCIAMS-174925 & $350-430$ & $380-425$ \\
\hline UCIAMS-174928 & $340-420$ & $345-420$ \\
\hline \multicolumn{3}{|l|}{ Phase b } \\
\hline Boundary & & $285-410$ \\
\hline UCIAMS-174931 & $240-380$ & $245-360$ \\
\hline UCIAMS-174921 & 225-335 & 235-335 \\
\hline \multicolumn{3}{|l|}{ Phase a } \\
\hline Boundary Start & & 140-335 \\
\hline Sequence & & \\
\hline
\end{tabular}


Figure 8. Model 1 results.

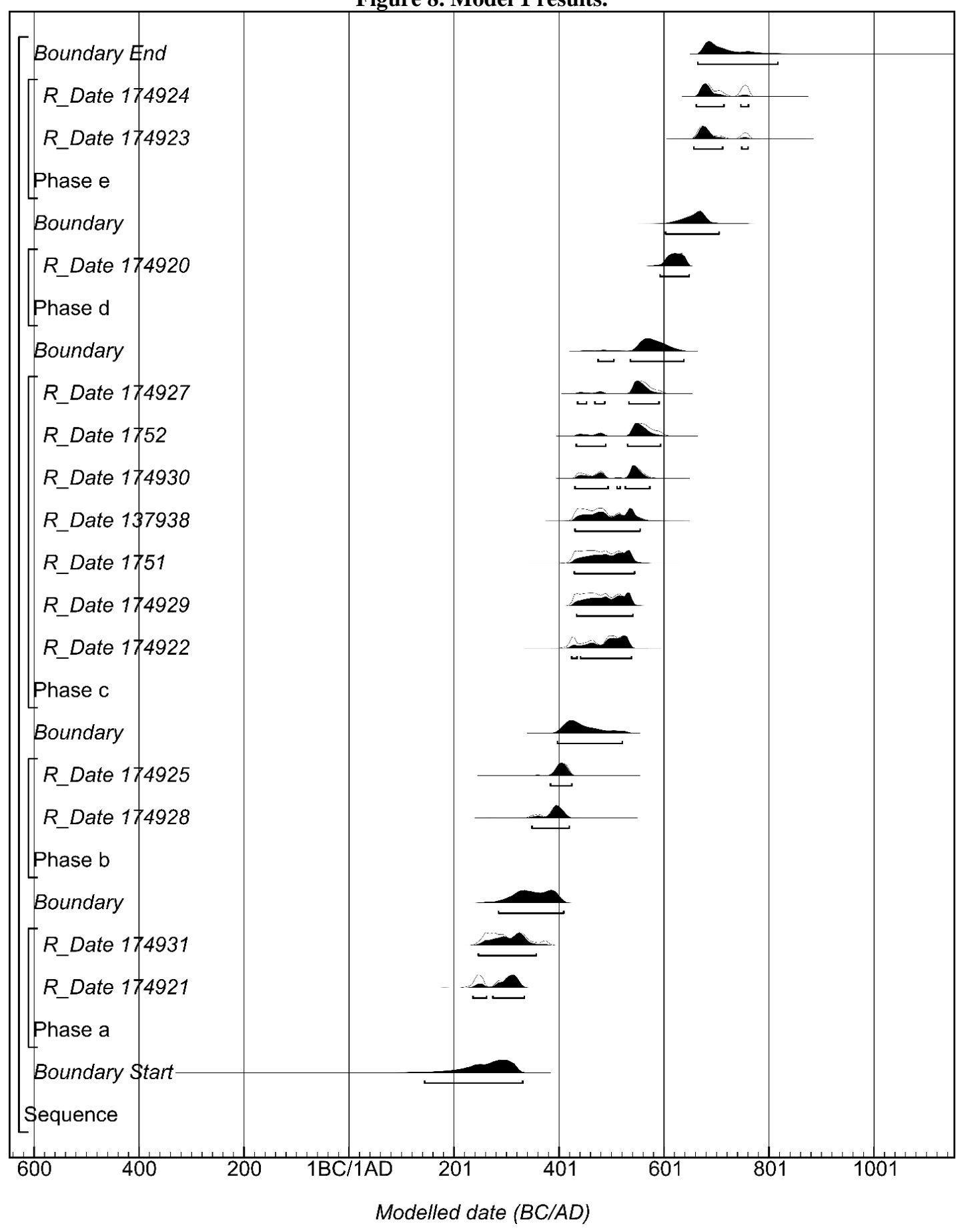

\section{Model 2: Phases}

Following the calculation of Model 1, we further explored the potential for episodic deposition of cervid remains at Par-Tee. Model 2 includes the previous assumptions that date clusters result from cultural exploitation of cervids and site use. However, we include an 
additional boundary seperating each individual phase with discrete start and ends (Table 8 and Figure 9). The boundaries would suggest more episodic site use with periods of no habitation.

The agreement indices for Model 2 are $A_{\text {model }}=117.3$ and $A_{\text {overall }}=110.5$.

Table 8. Model 2 results.

\begin{tabular}{|c|c|c|}
\hline Model Description & $\begin{array}{l}\text { Unmodelled cal AD (95.4\% } \\
\text { CI) }\end{array}$ & Modelled cal AD (95.4\% CI) \\
\hline Difference Span & & 375 to 750 cal yr \\
\hline Boundary End & & 670-895 \\
\hline Boundary End e & & $665-780$ \\
\hline UCIAMS-174924 & $665-770$ & $660-765$ \\
\hline UCIAMS- 174923 & $655-770$ & $660-765$ \\
\hline \multicolumn{3}{|l|}{ Phase e } \\
\hline Boundary Start e & & $625-760$ \\
\hline Boundary End d & & $595-685$ \\
\hline UCIAMS- 174920 & $590-650$ & $590-650$ \\
\hline \multicolumn{3}{|l|}{ Phase d } \\
\hline Boundary Start d & & $540-645$ \\
\hline Boundary End c & & $440-610$ \\
\hline UCIAMS- 174927 & $435-605$ & $435-580$ \\
\hline PSUAMS-1752 & $430-605$ & $435-580$ \\
\hline UCIAMS- 174930 & $430-575$ & 430-570 \\
\hline UCIAMS- 137938 & 425-555 & $435-560$ \\
\hline PSUAMS-1751 & $425-540$ & $435-550$ \\
\hline UCIAMS-174929 & $425-540$ & $435-545$ \\
\hline UCIAMS-174922 & $415-540$ & $440-545$ \\
\hline Boundary Start c & & 415-535 \\
\hline Boundary End b & & $385-480$ \\
\hline UCIAMS- 174925 & $350-430$ & $380-425$ \\
\hline UCIAMS- 174928 & $340-420$ & $360-425$ \\
\hline \multicolumn{3}{|l|}{ Phase $b$} \\
\hline Boundary Start b & & $320-415$ \\
\hline Boundary End a & & 255-385 \\
\hline UCIAMS-174931 & 240-380 & 245-345 \\
\hline UCIAMS-174921 & 225-335 & 240-335 \\
\hline \multicolumn{3}{|l|}{ Phase a } \\
\hline Boundary Start a & & 205-335 \\
\hline Boundary Start & & $80-325$ \\
\hline Sequence & & \\
\hline
\end{tabular}

Figure 9. Model 2 results. 


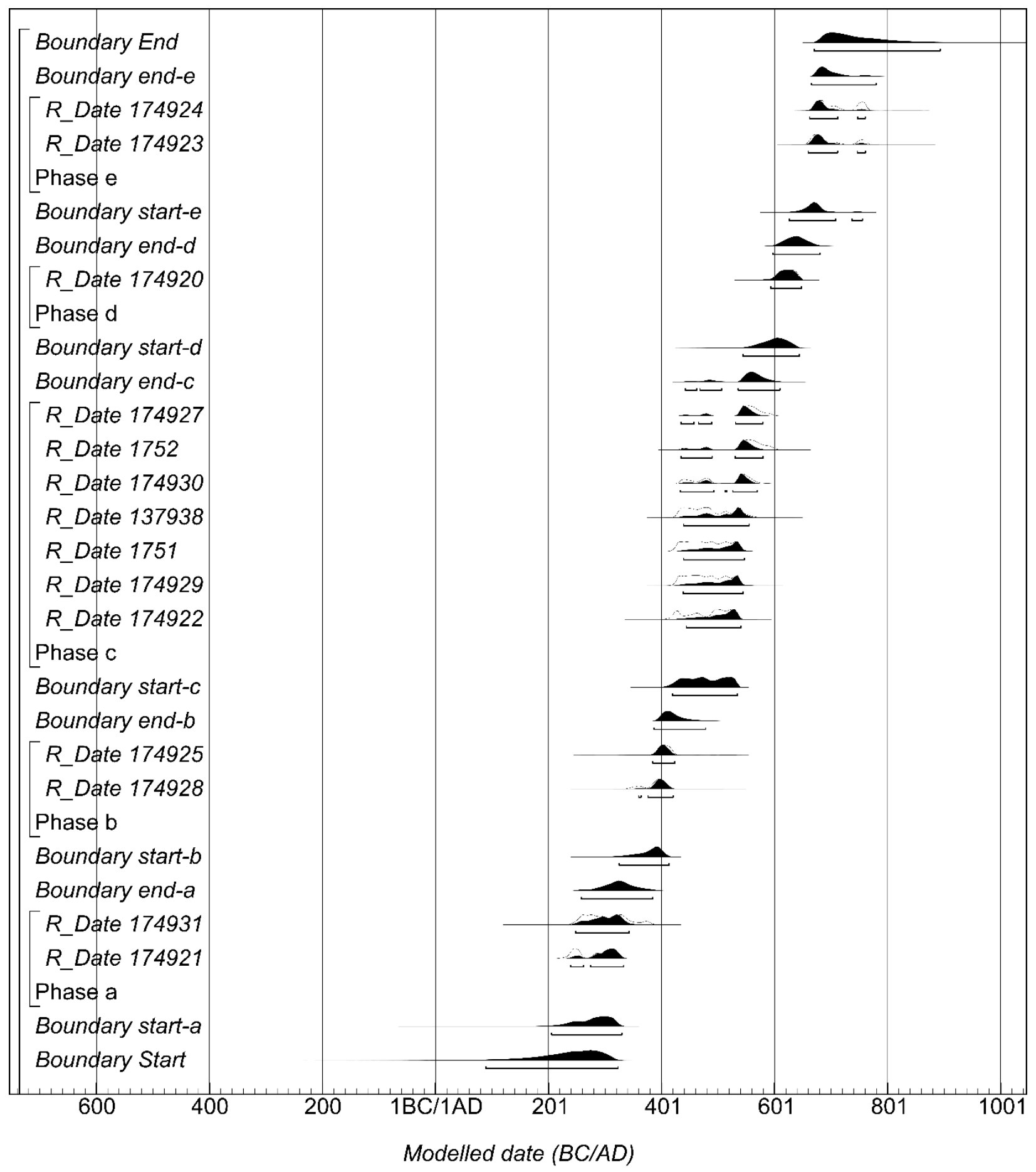

\section{Discussion}

The Bayesian analysis and calibration of the latest $\mathrm{AMS}{ }^{14} \mathrm{C}$ dates of the Par-Tee site suggest the site was occupied between cal AD 200 and cal AD 800 based on the unmodeled radiocarbon calibrations. The Bayesian models that explored the potential for discrete or episodic use of the site, suggest that although the Par-Tee site likely witnessed an intense occupation period at cal AD 400-650, the site was occupied at a maximum from cal $\sim$ AD 100-900, as evidenced in models 1 and 2 . These new data constrain the overall occupation of the Par-Tee 
site, which was previously believed to have dated from 350 cal BC to cal AD 1150 a span of 1,500 years (Arbolino et al. 2005; Colten 2002; Losey and Yang 2007; Sanchez et al. 2016). The new high-precision $\mathrm{AMS}{ }^{14} \mathrm{C}$ dates restrict the occupation of the site by more than half, from a period of $\sim 1,500$ years to $\sim 700$ years. This more restricted date range is consistent with two AMS ${ }^{14} \mathrm{C}$ dates obtained by Sanchez et al. (2016), one for a whale phalanx and a second for a cervid bone harpoon tip embedded in it. AMS dates on marine shells may expand the age range by a century or two closer to 100 BC (Losey and Yang 2007), but uncertainties about spatial and temporal fluctuations in the regional marine reservoir effect make us less confident in those calibrated ages.

Our reanalysis of the Par-Tee chronology supports previous interpretations of a later site use, which we date to cal AD 1490-1635, potentially contemporaneous with the use of the shell midden as a cemetery site (Arbolino et al. 2005). Further research of the Par-Tee assemblage is required to understand this later occupation. If ethnographic and ethnohistoric patterns of burying the dead in locations away from primary residences are consistent with the burial practices at Par-Tee, people may have used the site to bury their dead away from residential areas (Arbolino et al. 2005).

The revised chronology of the Par-Tee site suggests that our general understanding of the habitation of the broader Seaside region remains constant. At this time, Palmrose appears to be the most ancient of the three sites, followed by Avenue Q, and lastly Par-Tee. However, as the radiocarbon dates for Palmrose and Avenue $Q$ are derived from unidentified charcoal samples with a high range of uncertainty $(\geq \pm 60)$, refined dating efforts may change the chronology of human occupation at these sites, as well.

Our study minimizes one barrier to conducting research with the Par-Tee assemblage through the establishment of a more reliable chronology. The new ${ }^{14} \mathrm{C}$ dates for the Par-Tee site provide a well-defined and more constrained chronology for the analysis of the large artifact and faunal assemblage. The revised chronology enhances forthcoming and future research of the ParTee collection by allowing the cultural practices, material culture, and environmental data in the collection to be placed on a reliable chronological foundation.

\section{Conclusion}

Our ${ }^{14} \mathrm{C}$ dating of the Par-Tee museum specimens suggests that archaeologists should interpret historically reported ${ }^{14} \mathrm{C}$ dates with caution, especially those derived from composite samples of charcoal, bone, and shell and unidentified charcoal samples. In addition, our findings highlight the value of reanalyzing legacy collections with improved dating techniques. Although there appears to be more intensive use of the Par-Tee site between cal AD 400-650, the majority of the Par-Tee site collection is best viewed as the result of a single long-term $\sim 700-800$ year occupation.

We recommend that researchers working with legacy collections assess previously reported ${ }^{14} \mathrm{C}$ dates for an assemblage for chronometric hygiene. In those instances where previous ${ }^{14} \mathrm{C}$ dates are lacking, fieldnotes and maps are incomplete, or available resources limit the number of ${ }^{14} \mathrm{C}$ samples obtainable, researchers can use Bayesian chronological modeling software to estimate the quantity of dates needed and to produce precise and accurate models where stratigraphic information is missing or coarse-grained excavation methods prevent the use of essential stratigraphic information (Hamilton and Krus 2018). As AMS dates continue to become less costly, the type of chronological work we conducted at Par-Tee is becoming increasingly accessible to researchers at other museums and repositories around the world. 
In conclusion, the revised chronology of the Par-Tee site and the recent collections improvement work of the archaeological assemblage at the Smithsonian Institution will lead to further research of the large and diverse Par-Tee assemblage. Ultimately, our work reinforces studies that demonstrate the value of revisiting and building new chronologies in a Bayesian framework for important legacy collections housed in museums around the world (Jew et al. 2015; Kennett et al. 2011; Kennett et al. 2014; Thulman 2017). In addition, the integration of collagen fingerprinting and high-resolution AMS dating allows for precision in dating and calibration that can enhance the value of museum collections for topics of broad interest to archaeologists and other researchers, while minimizing impacts of research on museum collections.

Appendix 1. Summary of ${ }^{14} \mathrm{C}$ reported by Phebus and Drucker.

\begin{tabular}{|c|c|c|c|c|c|c|}
\hline Lab \# & $\begin{array}{l}\text { Year } \\
\text { submitted }\end{array}$ & Provenience & Stratigraphic context & $\begin{array}{l}\text { Material } \\
\text { dated }\end{array}$ & $\begin{array}{l}\text { Measured } \\
{ }^{14} \mathrm{C} \text { age }\end{array}$ & Notes \\
\hline SI-1565 & 1973 & $\begin{array}{l}\text { SE10L, level 5, } \\
\text { 52-54" }\end{array}$ & $\begin{array}{l}\text { Associated with bone chisel } \\
\text { fragment; clam shell layer }\end{array}$ & $\begin{array}{l}\text { Charcoal, } \\
\text { fine shell }\end{array}$ & $1035 \pm 65$ & \\
\hline SI-1566 & 1973 & $\begin{array}{l}\text { SE10L, level 6, } \\
\text { 66-68" }\end{array}$ & $\begin{array}{l}\text { Associated with blade } \\
\text { fragment and adze handle; } \\
\text { humus, ash layer }\end{array}$ & $\begin{array}{l}\text { Charcoal, } \\
\text { fine shell }\end{array}$ & $1090 \pm 65$ & $\begin{array}{l}\text { Sample } \\
\text { appears to } \\
\text { crosscut } \\
\text { two strata. }\end{array}$ \\
\hline SI-1567 & 1973 & $\begin{array}{l}\text { SE10L, level 8, } \\
84-86 "\end{array}$ & $\begin{array}{l}\text { Mussel shell, clam shell } \\
\text { layer }\end{array}$ & $\begin{array}{l}\text { Charcoal, } \\
\text { fine shell }\end{array}$ & $\begin{array}{l}1540 \pm \\
105\end{array}$ & \\
\hline SI-1568 & 1973 & $\begin{array}{l}\text { SE10L, level 9, } \\
\text { 98-100" }\end{array}$ & $\begin{array}{l}\text { Associated with chisel } \\
\text { fragment; clam shell layer }\end{array}$ & $\begin{array}{l}\text { Charcoal, } \\
\text { fine shell }\end{array}$ & $1645 \pm 65$ & \\
\hline SI-1569 & 1973 & $\begin{array}{l}\text { SE10L, level 10, } \\
108-110 "\end{array}$ & $\begin{array}{l}\text { Associated with chisel } \\
\text { fragment; ash, humus, } \\
\text { mussel shell layer }\end{array}$ & $\begin{array}{l}\text { Charcoal, } \\
\text { fine shell }\end{array}$ & $1575 \pm 65$ & $\begin{array}{l}\text { Sample } \\
\text { possibly } \\
\text { crosscuts } \\
\text { two strata. }\end{array}$ \\
\hline SI-1570 & 1973 & $\begin{array}{l}\text { SE10L, level 10, } \\
\text { 116-118" }\end{array}$ & Clam shell layer & $\begin{array}{l}\text { Charcoal, } \\
\text { fine shell }\end{array}$ & $1705 \pm 65$ & \\
\hline SI-776 & 1972 & $\begin{array}{l}\text { SE5G, level 8, } \\
35 " \text { E, 25" }\end{array}$ & Circular fire hearth & Charcoal & $1395 \pm 90$ & $\begin{array}{l}\text { Corrected } \\
\text { for isotopic } \\
\text { fractionatio } \\
\mathrm{n}\end{array}$ \\
\hline SI-777 & 1972 & $\begin{array}{l}\text { SE5H, 108- } \\
110 ", \text { SW 1/4 }\end{array}$ & & Charcoal & $1300 \pm 80$ & $\begin{array}{l}\text { Corrected } \\
\text { for isotopic } \\
\text { fractionatio } \\
\mathrm{n}\end{array}$ \\
\hline SI-4964 & 1981 & $\begin{array}{l}\text { SW20G, level 3, } \\
24-26 "\end{array}$ & $\begin{array}{l}\text { Shell midden mixed with } \\
\text { dietary bone and stratified } \\
\text { with humus }\end{array}$ & Charcoal & $1000 \pm 65$ & $\begin{array}{l}\text { Lab data } \\
\text { sheet also } \\
\text { reports a } \\
\text { second date } \\
\text { for this } \\
\text { sample of } \\
1285 \pm 70 ; \\
\text { sample } \\
\text { cross-cut } \\
\text { two strata }\end{array}$ \\
\hline SI-4965 & 1981 & $\begin{array}{l}\text { SW20G, level 3, } \\
28-30 "\end{array}$ & $\begin{array}{l}\text { Shell midden mixed with } \\
\text { dietary bone and stratified } \\
\text { with humus }\end{array}$ & Charcoal & $1170 \pm 70$ & \\
\hline SI-4966 & 1981 & $\begin{array}{l}\text { SW20G, level 4, } \\
38-40 "\end{array}$ & $\begin{array}{l}\text { Shell midden mixed with } \\
\text { dietary bone and stratified } \\
\text { with humus, ash, clam shell }\end{array}$ & Charcoal & $1295 \pm 70$ & $\begin{array}{l}\text { Lab data } \\
\text { sheet also } \\
\text { reports a } \\
\text { second date } \\
\text { for this } \\
\text { sample of }\end{array}$ \\
\hline
\end{tabular}




\begin{tabular}{|c|c|c|c|c|c|c|}
\hline & & & & & & $1580 \pm 70$ \\
\hline SI-4967 & 1981 & $\begin{array}{l}\text { SW20G, level 4, } \\
46-48 "\end{array}$ & $\begin{array}{l}\text { Shell midden mixed with } \\
\text { dietary bone and stratified } \\
\text { with humus, ash, clam shell }\end{array}$ & Charcoal & $1195 \pm 80$ & $\begin{array}{l}\text { Sample } \\
\text { crosscuts } \\
\text { three strata. }\end{array}$ \\
\hline SI-4968 & 1981 & $\begin{array}{l}\text { SW20G, level 5, } \\
58-60 "\end{array}$ & $\begin{array}{l}\text { Shell midden mixed with } \\
\text { dietary bone and stratified } \\
\text { with humus }\end{array}$ & Charcoal & $1655 \pm 75$ & $\begin{array}{l}\text { Sample } \\
\text { crosscuts } \\
\text { two strata. }\end{array}$ \\
\hline SI-4969 & 1981 & $\begin{array}{l}\text { SW21G, level 6, } \\
66-68 "\end{array}$ & $\begin{array}{l}\text { Shell midden mixed with } \\
\text { dietary bone and stratified } \\
\text { with humus }\end{array}$ & Charcoal & $1265 \pm 70$ & \\
\hline SI-4963 & 1981 & $\begin{array}{l}\text { SW19C- } \\
\text { SW20C, level 4, } \\
\text { mortuary } \\
\text { features C, D, E }\end{array}$ & $\begin{array}{l}\text { Mostly humus zone; minor } \\
\text { amounts of clam shell, } \\
\text { dietary bone and roots }\end{array}$ & $\begin{array}{l}\text { Human } \\
\text { rib }\end{array}$ & $1755 \pm 75$ & $\begin{array}{l}\text { Corrected } \\
\text { for isotopic } \\
\text { fractionatio } \\
\mathrm{n}\end{array}$ \\
\hline SI-653 & 1970 & NE12F, level 5 & $\begin{array}{l}\text { Loose clam and mussel } \\
\text { shell stratum }\end{array}$ & Charcoal & $\begin{array}{l}2055 \pm \\
125\end{array}$ & $\begin{array}{l}\text { Date also } \\
\text { reported as } \\
2035 \pm 125\end{array}$ \\
\hline SI-654 & 1970 & $\begin{array}{l}\text { NE12F, level } \\
6 / 7\end{array}$ & Humus and clam stratum & Charcoal & $1245 \pm 145$ & $\begin{array}{l}\text { Date also } \\
\text { reported as } \\
1225 \pm 145 \\
\end{array}$ \\
\hline SI-587 & 1969 & $\begin{array}{l}\text { NE12G, level 5, } \\
53 \text { " b.s. }\end{array}$ & $\begin{array}{l}\text { Associated with an 'antler' } \\
\text { atlatl }\end{array}$ & Charcoal & $1820 \pm 90$ & \\
\hline SI-655 & 1970 & NE12G, level 9 & $\begin{array}{l}\text { Compacted clam shell and } \\
\text { subsoil gravel below humus } \\
\text { stratum }\end{array}$ & Charcoal & $\begin{array}{l}1380 \pm \\
100\end{array}$ & $\begin{array}{l}\text { Date also } \\
\text { reported as } \\
1360 \pm 100\end{array}$ \\
\hline SI-616 & 1969 & $\begin{array}{l}\text { NE14G, level 6, } \\
\text { 60-62" b.s. }\end{array}$ & & Charcoal & $1450 \pm 90$ & $\begin{array}{l}\text { Depth is } \\
\text { below } \\
\text { datum, not } \\
\text { below } \\
\text { surface as } \\
\text { reported. }\end{array}$ \\
\hline SI-615 & 1969 & $\begin{array}{l}\text { NE14G, level 7, } \\
80 \text { " b.s. }\end{array}$ & & Charcoal & $2110 \pm 90$ & $\begin{array}{l}\text { Depth is } \\
\text { below } \\
\text { datum, not } \\
\text { below } \\
\text { surface as } \\
\text { reported. }\end{array}$ \\
\hline SI-588 & 1969 & $\begin{array}{l}\text { NE14G, level 8, } \\
87 \text { " b.s. }\end{array}$ & & Charcoal & $\begin{array}{l}3140 \pm \\
100\end{array}$ & $\begin{array}{l}\text { Depth is } \\
\text { below } \\
\text { datum, not } \\
\text { below } \\
\text { surface as } \\
\text { reported }\end{array}$ \\
\hline SI-656 & 1970 & $\begin{array}{l}\text { NE15F, level } \\
7 / 8\end{array}$ & Compacted clam shell & Charcoal & $\begin{array}{l}1905 \pm \\
125\end{array}$ & $\begin{array}{l}\text { Date also } \\
\text { reported as } \\
1895 \pm 125 \\
\end{array}$ \\
\hline SI-657 & 1970 & NE17F, level 8 & $\begin{array}{l}\text { Compacted clam shell, } \\
\text { gravel, and humus }\end{array}$ & Charcoal & $\begin{array}{l}1485 \pm \\
145\end{array}$ & $\begin{array}{l}\text { Date also } \\
\text { reported as } \\
1465 \pm 145 \\
\end{array}$ \\
\hline SI-658 & 1970 & NE18F, level 8 & $\begin{array}{l}\text { Compacted clam shell, } \\
\text { humus and beach rock }\end{array}$ & Charcoal & $\begin{array}{l}1685 \pm \\
105\end{array}$ & $\begin{array}{l}\text { Date also } \\
\text { reported as } \\
1665 \pm 105 \\
\end{array}$ \\
\hline
\end{tabular}

\section{Acknowledgements}

The authors thank the Department of Anthropology at the Smithsonian Institution's National Museum of Natural History (NMNH) for providing access to the samples used in this study. An NSF Archaeometry grant (BCE-1438889) awarded to the Human Paleoecology and Isotope Geochemistry Laboratory at Pennsylvania State University (PSU) provided support for this project. The authors are especially indebted to Teresa Hsu for her assistance in accessing the Par- 
Tee collections. Many thanks to the editor Christopher Hunt and two anonymous reviewers whose helpful comments improved the manuscript. A National Science Foundation Graduate Research Fellowship (DGE 1106400) and a National Science Foundation Graduate Research Internship Program (GRIP) Fellowship supported Gabriel Sanchez's research and Mike Buckley was supported by a Royal Society University Research Fellowship (UF120473). In addition, we thank Adrianna Allen of Photon Illustration for drafting Figures 3-6 and Katrina Eichner and David Hyde for assistance in identifying the historic era artifacts. Sanchez would also like to thank Richard Rosencrance for providing comments on an early draft of this paper.

\section{References}

Aikens, Melvin C., Thomas J. Connolly, and Dennis L. Jenkins

2011 Oregon Archaeology. 1st ed. Corvallis: Oregon State University Press.

Ames, Kenneth M.

1996 Life in the Big House: Household Labor and Dwelling Size on the Northwest Coast. In People Who Lived in Big Houses: Archaeological Perspectives on Large Domestic Structures. Gary Coupland and Edward Bruce Banning, eds. pp. 131-150. Madison, Wisconsin: Prehistory Press.

2003 The Northwest Coast. Evolutionary Anthropology: Issues, News, and Reviews 12(1): 1933.

Ames Kenneth M. and Herbert D.G. Maschner

1999 Peoples of the Northwest Coast: Their Archaeology and Prehistory. London: Thames and Hudson.

Arbolino, Risa Diemond., Stephen D Ousley, and Erica Bubniak-Jones

2005 Reassessment of the Cultural Affiliation of Human Remains and Funerary Objects from Seaside, Oregon at the National Museum of Natural History, Smithsonian Institution.

Washington, D.C.: Repatriation Office, National Museum of Natural History.

Ashmore, Patrick J.

1999 Radiocarbon Dating: Avoiding Errors by Avoiding Mixed Samples. Antiquity 73(279): 124-130.

Bawaya, Michael

2007 Curation in Crisis. Science 317(5841): 1025-1026.

Bayliss, Alex, Christopher Bronk Ramsey, Johannes van der Plicht, and Alasdair Whittle 2007 Bradshaw and Bayes: Towards a Timetable for the Neolithic. Cambridge Archaeological Journal 17(1): 1-28.

Bayliss, Alex, and Christopher Bronk Ramsey

2004 Pragmatic Bayesians: A Decade of Integrating Radiocarbon Dates into Chronological Models. In Tools for Constructing Chronologies. Caitlin E. Buck and Andrew R. Millard, eds. pp. 25-41. Lecture Notes in Statistics, 177. Springer London. 
Bronk Ramsey, Christopher

1995 Radiocarbon Calibration and Analysis of Stratigraphy: The OxCal Program. Radiocarbon 37(2): 425-430.

Bronk Ramsey, Christopher, Thomas Higham, and Philip Leach

2004 Towards High-Precision AMS: Progress and Limitations. Radiocarbon 46(01): 17-24.

Brown, Thomas A., Earle D. Nelson, John S. Vogel, and John R. Southon

1988 Improved Collagen Extraction by Modified Longin Method. Radiocarbon 30(2): 171177.

Buck, Caitlin E., James B. Kenworthy, Cliff D. Litton, and Adrian F.M. Smith

1991 Combining Archaeological and Radiocarbon Information: A Bayesian Approach to Calibration. Antiquity 65(249): 808-821.

Buckley, Michael, Matthew Collins, and Jane Thomas-Oates 2008 A Method of Isolating the Collagen (I) A2 Chain Carboxytelopeptide for Species Identification in Bone Fragments. Analytical Biochemistry 374(2): 325-334.

Buckley, Michael, Matthew Collins, Jane Thomas-Oates, and Julie C. Wilson 2009 Species Identification by Analysis of Bone Collagen Using Matrix-Assisted Laser Desorption/Ionisation Time-of-Flight Mass Spectrometry. Rapid Communications in Mass Spectrometry 23(23): 3843-3854.

Buckley, Mike, Sarah Whitcher Kansa, Sarah Howard, Stuart Campbell, Jane Thomas-Oates, and Matthew Collins

2010 Distinguishing between Archaeological Sheep and Goat Bones Using a Single Collagen Peptide. Journal of Archaeological Science 37(1): 13-20.

Buckley, Mike, and Sarah W. Kansa

2011 Collagen Fingerprinting of Archaeological Bone and Teeth Remains from Domuztepe, South Eastern Turkey. Archaeological and Anthropological Sciences 3(3): 271-280.

Buckley, Michael, Sheena Fraser, Jeremy Herman, Nigel D. Melton, Jacqui Mulville, and Albína H. Pálsdóttir

2014 Species Identification of Archaeological Marine Mammals Using Collagen

Fingerprinting. Journal of Archaeological Science 41: 631-641.

Buckley, Michael, Richard G. Cooke, María F. Martínez, Fernando Bustamante, Máximo Jiménez, Alexandra Lara, and Juan G. Martín

2017 Archaeological Collagen Fingerprinting in the Neotropics; Protein Survival in 6000 Year Old Dwarf Deer Remains from Pedro González Island, Pearl Islands, Panama. In Zooarchaeology in the Neotropics: Environmental Diversity and Human-Animal Interactions. Mariana Mondini, Sebastián A. Muñoz, and Pablo M. Fernández, eds. pp. 157-175. Cham, Switzerland: Springer. 
Collins, Matthew, Michael Buckley, Helen H. Grundy, Jane Thomas-Oates, Julie Wilson, and Nienke van Doorn

2010 ZooMS: The Collagen Barcode and Fingerprints. Spectroscopy Europe 22(2): 6-10.

Colten, Roger $\mathrm{H}$.

2002 Prehistoric Marine Mammal Hunting in Context: Two Western North American Examples. International Journal of Osteoarchaeology 12(1): 12-22.

2015 Prehistoric Coastal Adaptations at Seaside, Oregon: Vertebrate Fauna from the Palmrose and Par-Tee Sites. The Journal of Island and Coastal Archaeology 10(2): 253-276.

Connolly, Thomas J.

1992 Human responses to change in coastal geomorphology and fauna on the Southern Northwest Coast: Archaeological Investigations at Seaside, Oregon. University of Oregon Anthropological Papers, 45. Eugene: Department of Anthropology and Oregon State Museum of Anthropology, University of Oregon.

1995 Archaeological Evidence for a Former Bay at Seaside, Oregon. Quaternary Research 43(3): 362-369.

Crowell, Elizabeth A.

2000 Walking in the Shadows of Archaeologists Past: Researching Museum Collections and Associated Records to Elucidate Past Lifeways. North American Archaeologist 21(2): 97-106.

Dee, Michael W., and Christopher Bronk Ramsey

2014 High-Precision Bayesian Modeling of Samples Susceptible to Inbuilt Age. Radiocarbon 56(1): 83-94.

DeNiro, Michael J.

1985 Postmortem Preservation and Alteration of in Vivo Bone Collagen Isotope Ratios in Relation to Palaeodietary Reconstruction. Nature 317(6040): 806-809.

Drucker, Philip.

1955 Indians of the Northwest Coast. New York: McGraw-Hill for the American Museum of Natural History.

Erlandson, Jon M., and Thomas Rockwell

1987 Radiocarbon Reversals and Stratigraphic Discontinuities: Natural Formation Processes in Coastal California Archaeological Sites. In Natural Formation Processes and the Archaeological Record. David T. Nash and Michael D. Petraglia, eds. pp. 51-73. British Archaeological Reports International Series, 352.

Erlandson, Jon M., and Madonna L. Moss

1999 The Systematic Use of Radiocarbon Dating in Archaeological Surveys in Coastal and Other Erosional Environments. American Antiquity 64(3): 431-433.

Finstad, Kari M., B. Lynn Ingram, Peter Schweikhardt, Kent G. Lightfoot, Edward M. Luby, and 
George R. Coles

2013 New Insights about the Construction and Use of Shell Mounds from the Geochemical Analysis of Mollusks: An Example from the Greater San Francisco Bay. Journal of Archaeological Science 40(6): 2648-2658.

Fitzpatrick, Scott M., and Nicholas P. Jew

2018 Radiocarbon Dating and Bayesian Modelling of One of Remote Oceania's Oldest Cemeteries at Chelechol Ra Orrak, Palau. Antiquity 92(361): 149-164.

Goddard Pliny E.

1945 Indians of the Northwest Coast. 2nd edition. American Museum of Natural History Handbook Series, no. 10. New York: American Museum of Natural History.

Hamilton, W. Derek, and Anthony M. Krus

2018 The Myths and Realities of Bayesian Chronological Modeling Revealed. American Antiquity 83:187-203.

Hoggarth, Julie A., Brendan J. Culleton, Jaime J. Awe, and Douglas J. Kennett 2014 Questioning Postclassic Continuity at Baking Pot, Belize, Using Direct AMS 14C Dating of Human Burials. Radiocarbon 56(3): 1057-1075.

Hunt, Terry L., and Carl P. Lipo

2006 Late Colonization of Easter Island. Science 311(5767): 1603-1606.

Huster, Angela

2013 Assessing Systematic Bias in Museum Collections: A Case Study of Spindle Whorls. Advances in Archaeological Practice 1(2): 77-90.

Jacobs, Elizabeth D.

2003 The Nehalem Tillamook: An Ethnography. Corvallis: Oregon State University Press.

Jew, Nicholas P., Torben C. Rick, Michael A. Glassow, and Jeanne E. Arnold

2015 Bayesian 14 C Analysis, Formation Processes, and Accumulation Rates of the Prisoners Harbor Shell Midden and Village Complex, Santa Cruz Island, California. Journal of Archaeological Science: Reports 3: 257-264.

Kennett, Douglas J., Brendan J. Culleton, Jaime Dexter, Scott A. Mensing, and David Hurst Thomas

2014 High-Precision AMS 14 C Chronology for Gatecliff Shelter, Nevada. Journal of Archaeological Science 52: 621-632.

Kennett, Douglas J., Brendan J. Culleton, Barbara Voorhies, and John R. Southon 2011 Bayesian Analysis of High-Precision AMS 14C Dates from a Prehistoric Mexican Shellmound. Radiocarbon 53(2): 245-259.

Kennett, Douglas J., Lynn B. Ingram, John R. Southon, and Karen Wise 2002 Differences in 14 C Age Between Stratigraphically Associated Charcoal and Marine 
Shell from the Archaic Period Site of Kilometer 4, Southern Peru: Old Wood or Old Water? Radiocarbon 44(1): 53-58.

van Klinken, Gert J.

1999 Bone Collagen Quality Indicators for Palaeodietary and Radiocarbon Measurements. Journal of Archaeological Science 26(6): 687-695.

Kowalsky, Arnold A., and Dorothy E. Kowalsky

1999 Encyclopedia of Marks on American, English and European Earthenware, Ironstone and Stoneware (1780-1980): Makers, Marks, and Patterns in Blue and White, Historic Blue, Flow Blue, Mulberry, Romantic Transferware, Tea Leaf and White Ironstone. Schiffer Book for Collectors. Atglen, Pennsylvania: Schiffer Publishing.

Losey, Robert J.

2005 House Remains at the Netarts Sandspit Village, Oregon. Journal of Field Archaeology 30(4): 401-417.

2010 Archaeology of the Par-Tee Site, Northern Oregon Coast. Retrieved from https://sites.ualberta.ca/ rlosey/partee/, accessed July $9^{\text {th }}, 2018$.

Losey, Robert J., and Eleanor A. Power 2005 Shellfish Remains from the Par-Tee Site (35-CLT-20), Seaside, Oregon: Making Sense of a Biased Sample. Journal of Northwest Anthropology 39(1): 1-20.

Losey, Robert J., and Dongya Y. Yang

2007 Opportunistic Whale Hunting on the Southern Northwest Coast: Ancient DNA, Artifact, and Ethnographic Evidence. American Antiquity 72(4): 657-676.

Luby, Edward M., Kent G. Lightfoot, and Victoria Bradshaw

2013 Archaeological Curation and the Research Value of Archaeological Collections: A Case Study from California. Collections: A Journal for Museum and Archives Professionals 9(3): 255-282.

Lyman, Lee R.

1991 Prehistory of the Oregon Coast : The Effects of Excavation Strategies and Assemblage Size on Archaeological Inquiry. San Diego: Academic Press.

McClure, Sarah B, Oreto Garcia Puchol, and Brendan J Culleton 2010 AMS Dating of Human Bone from Cova De La Pastora: New Evidence of Ritual Continuity in the Prehistory of Eastern Spain. Radiocarbon 52(1): 25-32.

Minor, Rick

1983 Aboriginal Settlement and Subsistence at the Mouth of the Columbia River. Unpublished Ph.D. Dissertation, University of Oregon.

Moss, Madonna 
2011 Northwest Coast: Archaeology as Deep History. Washington D.C.: The Society for American Archaeology Press.

Pearce, Susan M.

1994 Collecting Reconsidered. In Interpreting Objects and Collections. Susan M. Pearce, ed. pp. 193-204. Leicester Readers in Museum Studies. London: Routledge.

Pettitt, Paul B., William Davies, Clive S. Gamble, and Martin B. Richards

2003 Palaeolithic Radiocarbon Chronology: Quantifying Our Confidence beyond Two HalfLives. Journal of Archaeological Science 30(12): 1685-1693.

Phebus, George E. Jr., and Robert M. Drucker

1973 Archeological Investigations of the Northern Oregon Coast: A Brief Summary of Smithsonian Sponsored Excavations in the Seaside Area with Comments on the Archaeological Resources of Western Clatsop County. Washington D.C: Smithsonian Institution. Department of Anthropology.

1979 Archeological Investigations at Seaside, Oregon: An Intermediate Report on the Excavations of Two Major Archaeological Sites at Seaside Oregon, Through September, 1977. Seaside, Oregon: Seaside Museum and Historical Society.

Reimer, Paula J., Edouard Bard, Alex Bayliss, Warren J. Beck, Paul G. Blackwell, Christopher Bronk Ramsey, Caitlin E. Buck, Hai Cheng, Lawrence R. Edwards, and Michael Friedrich 2013 IntCal13 and Marine13 Radiocarbon Age Calibration Curves 0-50,000 Years Cal BP. Radiocarbon 55(4): 1869-1887.

Richter, Kristine K., Julie Wilson, Andrew K.G. Jones, Michael Buckley, Nienke van Doorn, and Matthew J. Collins

2011 Fish'n Chips: ZooMS Peptide Mass Fingerprinting in a 96 Well Plate Format to Identify Fish Bone Fragments. Journal of Archaeological Science 38(7): 1502-1510.

Rick, Torben C.

2007 Household and Community Archaeology at the Chumash Village of Niaqla, Santa Rosa Island, California. Journal of Field Archaeology 32(3): 243-263.

Rybczynski, Natalia, John C. Gosse, C. Richard Harington, Roy A. Wogelius, Alan J. Hidy, and Michael Buckley

2013 Mid-Pliocene Warm-Period Deposits in the High Arctic Yield Insight into Camel Evolution. Nature Communications 4: 1550.

Sanchez, Gabriel M., Jon M. Erlandson, Brendan J. Culleton, Douglas J. Kennett, and Torben C. Rick

2016 High-Resolution AMS 14C Dates for the Par-Tee Site (35CLT20) and Prehistoric Whale Hunting on the Oregon Coast. Radiocarbon 58(2): 397-405.

Santos, Guaciara M., John R. Southon, Kevin C. Druffel-Rodriguez, Sheila Griffin, and Maya Mazon 
2004 Magnesium Perchlorate as an Alternative Water Trap in AMS Graphite Sample Preparation: A Report on Sample Preparation at KCCAMS at the University of California, Irvine. Radiocarbon 46(1): 165-173.

Schiffer, Michael B.

1986 Radiocarbon Dating and the "Old Wood" Problem: The Case of the Hohokam Chronology. Journal of Archaeological Science 13(1): 13-30.

Schweikhardt, Peter, B. Lynn Ingram, Kent Lightfoot, and Edward Luby 2011 Geochemical Methods for Inferring Seasonal Occupation of an Estuarine Shellmound: A Case Study from San Francisco Bay. Journal of Archaeological Science 38(9): 2301-2312.

Sholts, Sabrina B., Joshua A. Bell, and Torben C. Rick 2016 Ecce Homo: Science and Society Need Anthropological Collections. Trends in Ecology \& Evolution 31(8): 580-583.

Silverstein, Michael.

1990 Chinookans of the Lower Columbia. In William C. Sturtevant and Wayne Suttles, editors. Handbook of North American Indians Volume 7. pp. 533-46. Washington, DC: Smithsonian Institution.

van der Sluis, Laura G., Hege I. Hollund, Michael Buckley, Perry G.B. De Louw, Kenneth F. Rijsdijk, and Henk Kars 2014 Combining Histology, Stable Isotope Analysis and ZooMS Collagen Fingerprinting to Investigate the Taphonomic History and Dietary Behaviour of Extinct Giant Tortoises from the Mare Aux Songes Deposit on Mauritius. Palaeogeography, Palaeoclimatology, Palaeoecology 416: 80-91.

Speller, Camilla, Youri van den Hurk, Anne Charpentier, Ana Rodrigues, Armelle Gardeisen, Barbara Wilkens, Krista McGrath, Keri Rowsell, Luke Spindler, Matthew Collins, and Michael Hofreiter 2016 Barcoding the Largest Animals on Earth: Ongoing Challenges and Molecular Solutions in the Taxonomic Identification of Ancient Cetaceans. Philosophical Transactions of the Royal Society B: Biological Sciences 371(1702): 20150332.

Spriggs, Matthew

1989 The Dating of the Island Southeast Asian Neolithic: An Attempt at Chronometric Hygiene and Linguistic Correlation. Antiquity 63(240): 587-613.

Stuiver, Minze, Gordon W. Pearson, and Tom Braziunas 1986 Radiocarbon Age Calibration of Marine Samples Back to 9000 Cal Yr BP. Radiocarbon 28(2): 980-1021.

Stuiver, Minze, and Henry A. Polach

1977 Discussion: Reporting of C-14 Data. Radiocarbon 19(3): 355-363. 
Taylor, Royal Ervin

1991 Radioisotope Dating by Accelerator Mass Spectrometry: Archaeological and Paleoanthropological Perspectives. In Scientific Dating Methods. H. Y. Göksu, Martin Oberhofer, and D. F. Regulla, eds. pp. 37-54. Euro Courses. Advanced Scientific Techniques. Dordrecht: Kluwer Academic.

Thulman, David K.

2017 Dust Cave Revisited: A Bayesian Reanalysis of the Radiocarbon Record. American Antiquity 82(1): 168-182.

Voss, Barbara L.

2012 Curation as Research. A Case Study in Orphaned and Underreported Archaeological Collections. Archaeological Dialogues 19(2): 145-169.

Wellman, Hannah P., Torben C. Rick, Antonia T. Rodrigues, and Dongya Y. Yang 2017 Evaluating Ancient Whale Exploitation on the Northern Oregon Coast Through Ancient DNA and Zooarchaeological Analysis. The Journal of Island and Coastal Archaeology 12(2): $255-275$.

Wilmshurst, Janet M., Terry L. Hunt, Carl P. Lipo, and Atholl J. Anderson 2011 High-Precision Radiocarbon Dating Shows Recent and Rapid Initial Human Colonization of East Polynesia. Proceedings of the National Academy of Sciences 108(5): 1815-1820. 